ESTIMATES OF CONSUHPTIVE USE AND GROUND-HATER RETURN FLOH AND THE EFFECT OF RISING AND SUSTAINED HIGH RIVER STAGE ON THE METHOD OF ESTIMATION IN CIBOLA VALLEY, ARIZONA AND CALIFORNIA, 1983 AND 1984

By Sandra J. Owen-Joyce

U.S . GEOLOGICAL SURVEY

Water-Resources Investigations Report 89-4194

Prepared in cooperation with the

U.S. BUREAU OF RECLAMATION

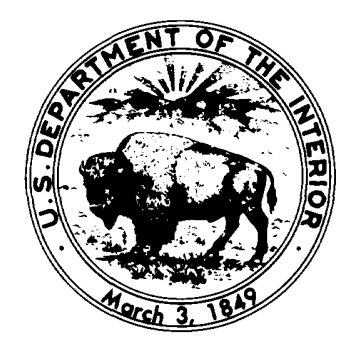


DEPARTMENT OF THE INTERIOR

MANUEL LUJAN, JR., Secretary

U.S. GEOLOGICAL SURVEY

Dallas L. Peck, Director

For additional information write to:

U.S. Geological Survey

Box FB-44

Federal Building 300 West Congress Street

Tucson, Arizona 85701-1393
Copies of this report can be purchased from:

U.S. Geological Survey Books and Open-File Reports Section Federal Center, Bldg. 810 Box 25425

Denver, Colorado 80225 


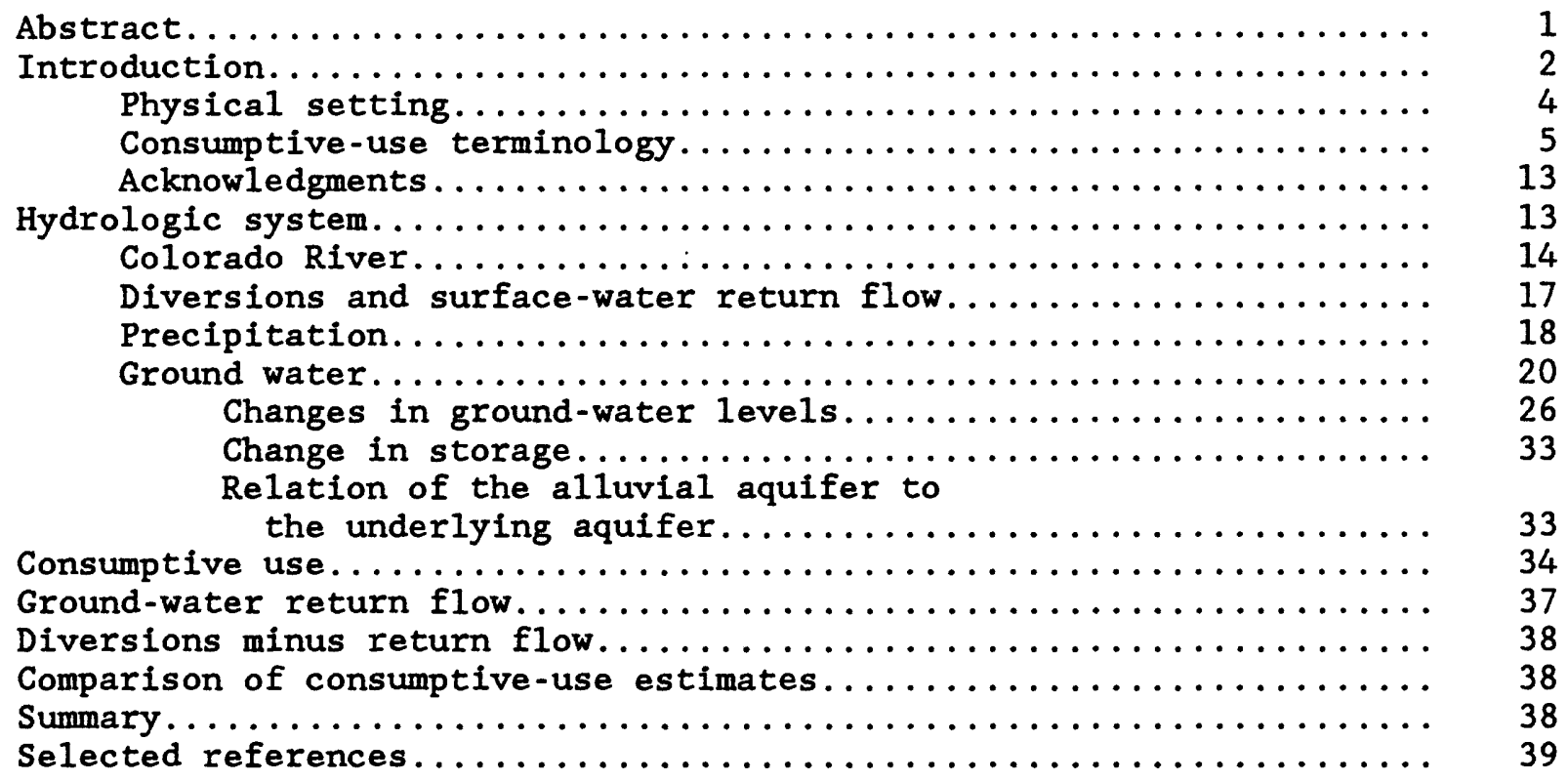

\section{IILUSTRATIONS}

Figures 1-3. Maps showing:

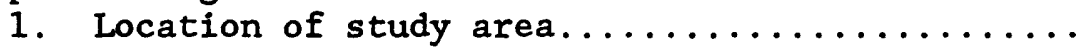

2. Cibola Valley and location of streamflowgaging stations and surface-water

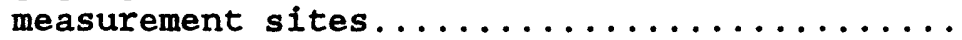

3. Cultivated land and phreatophyte areas in Cibola Valley, Arizona................

4-9. Graphs showing:

4. Annual acreages by crop type, total cropped area, and diversions in Cibola Valley, Arizona, $1981-84 \ldots \ldots \ldots \ldots \ldots \ldots \ldots \ldots . \ldots . \ldots 10$

5. Annual flow in the Colorado River, 1960-84.... 15

6. Daily mean flow in the Colorado River below Parker Dam, 1982-84............. 15

7. Daily mean flow in the Colorado River below Cibola valley, 1982-84............ 16

8. Daily mean gage height of the Colorado River at Cibola Cross Section No. 28, 1982-84..... 16

9. Annual precipitation at Ehrenberg, Arizona, 1941-84............................

10. Map showing average water-table altitude in Cibola Valley, Arizona and California, 1983........... 
Figures 11-13. Maps showing:

11. Average water-table altitude in Cibola

Valley, Arizona and California, 1984....... 24

12. Change in ground-water levels in Cibola

Valley, Arizona, February 1983-

December $1983 \ldots \ldots \ldots \ldots \ldots \ldots \ldots \ldots \ldots \ldots . \ldots \ldots$

13. Change in annual average ground-water levels

in Cibola Valley, Arizona, 1983-84........ 30

14-15. Graphs showing:

14. Water levels in selected wells in Cibola

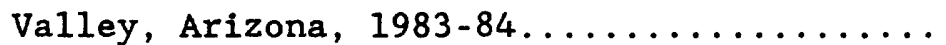

15. Water levels in a well in the fanglomerate aquifer and in three nearby wells in the alluvium, $1983-84 \ldots \ldots \ldots \ldots \ldots \ldots \ldots \ldots$

\section{TABLES}

Table 1. Estimates of evapotranspiration by vegetation in

Cibola Valley, Arizona and California, 1983-84....... 11

2. Diversions to Cibola Valley, Arizona, 1983-84.......... 17

3. Annual precipitation for Ehrenberg, Arizona, 1980-84...... 19

4. Average annual water-table altitudes in the shallow piezometers and change in head between the nearand far-cluster shallow piezometers along the Colorado River adjacent to Cibola Valley,

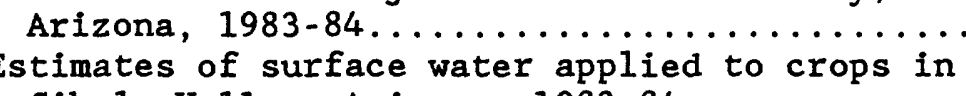
Cibola Valley, Arizona, $1983-84 \ldots \ldots \ldots \ldots \ldots \ldots \ldots \ldots \ldots$ 
For readers who prefer to use metric (International System) units rather than inch-pound units, the conversion factors for the terms used in this report are listed below:

Multiply inch-pound unit

By

To obtain metric unit

inch (in.)

25.4

millimeter (mm)

foot ( $f t$ )

0.3048

meter (m)

mile (mi)

1.609

kilometer $(\mathrm{km})$

square mile $\left(\mathrm{mi}^{2}\right)$

2.590

square kilometer $\left(\mathrm{km}^{2}\right)$

foot per mile

0.1894

meter per kilometer

$(\mathrm{ft} / \mathrm{mi})$

cubic foot per second

0.02832 $(\mathrm{m} / \mathrm{km})$

$\left(\mathrm{ft}^{3} / \mathrm{s}\right)$

0.4047

cubic meter per second $\left(\mathrm{m}^{3} / \mathrm{s}\right)$

acre

0.001233

square hectometer $\left(\mathrm{hm}^{2}\right)$

acre-foot (acre-ft)

cubic hectometer $\left(\mathrm{hm}^{3}\right)$

Sea level: In this report "sea leve1" refers to the National Geodetic Vertical Datum of 1929 (NGVD of 1929)-A geodetic datum derived from a general adjustment of the first-order level nets of both the United States and Canada, formerly called "Sea Level Datum of 1929." 


\title{
ESTIMATES OF CONSUMPTIVE USE AND GROUND-WATER RETURN FLOW AND THE EFFECT OF RISING AND SUSTAINED HIGH RIVER STAGE ON THE METHOD OF ESTIMATION IN CIBOLA VALLEY, ARIZONA AND CALIFORNIA, 1983 AND 1984
}

By

Sandra J. Owen-Joyce

\begin{abstract}
In Cibola Valley, Arizona, water is pumped from the Colorado River to irrigate crops and to maintain wildlife habitat. Unused water percolates to the water table and, as ground water, moves downgradient into areas of phreatophytes, into a drainage ditch, out of the flood plain into the bordering terraces, and back to the river.

Consumptive use by vegetation is a component in a water budget to estimate ground-water return flow to the river from applied irrigation water. Evapotranspiration was used as an approximation for consumptive use by vegetation. Evapotranspiration was calculated as the sum of the products of the areas of vegetation types and the water-use rates by vegetation type. Evapotranspiration was estimated to be 70,100 acre-feet in 1983 and 62,600 acre-feet in 1984. These estimates may be in error because of the effect of sustained inundation on the rate of water use by phreatophytes. The effects cannot be quantified and therefore adjustments to rates calculated for dry-surface conditions could not be made. In 1983 and 1984, ground-water return flow was negligible because in most of Cibola Valley the river lost water to the aquifer.
\end{abstract}

The method of estimating the consumptive use of water by vegetation and the ground-water return flow is affected by changing hydrologic conditions during years of rising and sustained high river stage caused by flood-control releases at Parker Dam. High river stage caused some areas to be flooded directly or raised ground-water levels above the land surface. No crops could be grown in flooded fields. The decreased depth to water and inundation with fresh water resulted in new phreatophyte growth in some areas. In some areas that were flooded, many phreatophytes died. Changes in the inundated and flooded areas throughout the years made it difficult to estimate evaporation losses from the increased water surface.

Changes in cropping patterns as a result of the Federal PaymentIn-Kind Program affected the estimation of consumptive use by vegetation. The relation between evapotranspiration and consumptive use by vegetation in Palo Verde Valley, which was assumed to be tranferable for use in Cibola Valley in 1981, could not be transferred for 1983 and 1984 . The relations between the two values in Palo Verde Valley were not the same in both years and the relations between the two values in Palo Verde and Parker Valleys - two valleys of similar size and crop mix were not the same. Therefore, transferability of the Palo Verde Valley relation to a smaller valley with a different crop mix and a larger percentage of its area flooded was not appropriate. 


\section{INTRODUCTION}

A decree by the U.S. Supreme Court (1964) apportions the waters of the lower Colorado River to the States of California, Arizona, and Nevada in terms of consumptive use. Consumptive use is defined in the decree as $" * * *$ diversions from the stream less such return flow thereto as is available for consumptive use* **." The decree requires that, for each diverter, the quantities of diversion and consumptive use be published annually.

Consumptive use of lower Colorado River water was estimated as diversions from the river minus surface-water and ground-water return flows. Diversions and surface-water return flows are based on direct measurements. Ground-water return flow cannot be measured but was estimated using a water budget for part of the flood-plain area in Palo Verde Valley, California, and Cibola Valley, Arizona (Owen-Joyce, 1984), and in Parker Valley, Arizona (Leake, 1984).

In Parker and Palo Verde Valleys, consumptive use of diverted river water by vegetation can be accurately estimated for areas where all the return flows are captured in drainage ditches. In the remaining areas, return flows seep directly to the river and can be estimated by using the consumptive-use rates developed for the areas with drainage ditches after those rates are adjusted for differences in the distribution of vegetation types. As there is no area where return flows are captured by drainage ditches, the method was modified for use in Cibola Valley (Owen-Joyce, 1984, p. 34). Consumptive use by vegetation was estimated by using vegetation types, acreages, and water-use rates for each vegetation type calculated using the Blaney-Criddle equation (Blaney and Criddle, 1950).

The U.S. Geological Survey, in cooperation with the U.S. Bureau of Reclamation, is developing a new method of calculating and apportioning consumptive use to lower Colorado River water users. The Colorado River between Parker Dam and Imperial Dam (fig. 1) is being used as a test site for the proposed new method. The estimate of consumptive use calculated from a surface-water budget (streamflow depletion) will be compared with the estimate of consumptive use calculated as diversions minus surfacewater and ground-water return flows. Consumptive use calculated as diversions minus return flows was estimated separately for each of the three valleys in the Parker Dam to Imperial Dam reach and documented in separate reports: Palo Verde Valley (Owen-Joyce and Kimsey, 1987), Parker Valley (Owen-Joyce, 1988), and Cibola Valley in this report.

This report describes that part of the study in which consumptive use by vegetation (crops and phreatophytes) and ground-water return flow in Cibola Valley were estimated for calendar years 1983 and 1984 using a modified version of the methodology described by Owen-Joyce (1984). Included in this report are (1) a brief description of the hydrologic system, (2) estimates of evapotranspiration, (3) estimates of ground-water return flow, (4) estimates of change in ground-water storage caused by rising and sustained high river stage, and (5) the effects of rising and 


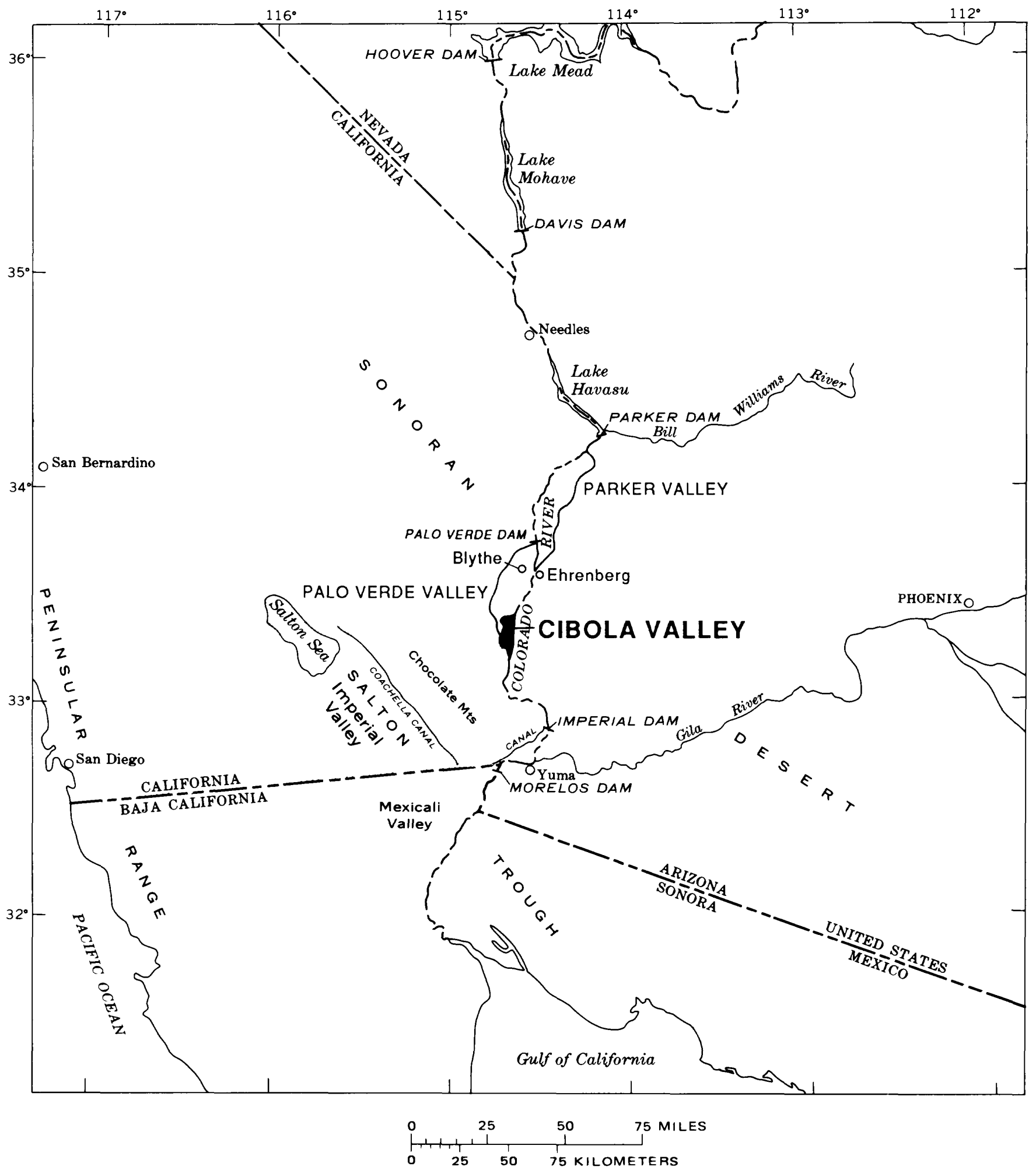

Figure 1.--Location of study area. 
sustained high river stage on the estimation of consumptive use by vegetation and ground-water return flow. All annual data values given in this report are for calendar years.

\section{Physical Setting}

Cibola Valley contains about $30 \mathrm{mi}^{2}$ of Colorado River flood plain in western La Paz County, Arizona, and eastern Imperial County, California (fig. 2). Cibola Valley is bounded on the north and west by the Colorado River, the old 1970 river channel, and the edge of the flood plain; on the east by the edge of the flood plain; and on the south by an arbitrary boundary where the flood plain narrows south of Cibola Lake. The main population centers are the town of Cibola and the community along the road built on the Gila and Salt River meridian base line (fig. 2). About 5,200 acres are cultivated east of the river and about 600 acres are cultivated between the old and new river channels (fig. 3). About 12,400 acres are covered with phreatophytes.

Cibola Valley, Arizona, was divided into three areas in a previous study because of the location of a ground-water divide, multiple points of pumping from the Colorado River, and different usage for diverted water (Owen-Joyce, 1984, p. 35). The three areas are: (1) Cibola Valley Irrigation and Drainage District, which is north of the Gila and Salt River meridian base line (fig. 2); (2) Cibola National Wildlife Refuge and other land south of the Gila and Salt River meridian base line and east of the Colorado River in Arizona (area A on fig. 2); and (3) Arizona land between the old and new Colorado River channels (area B on fig. 2). For this study, a fourth area (area $C$ on fig. 2) was added, which contains that part of the flood plain in California west of the old channel and north of the southernmost gaging station (fig. 2 , site 4 ).

In 1981, Cibola Valley Irrigation and Drainage District contained all the irrigated land under which ground water flowed to the river. In Cibola National Wildife Refuge, some of the water pumped from the river (fig. 2) is used to irrigate crops and some is used to maintain the wildlife habitat. In 1983 and 1984, a drainage ditch was dug in Cibola National Wildlife Refuge about $0.5 \mathrm{mi}$ from and parallel to the east flood-plain boundary (fig. 3 ).

Cultivated land between the old and new river channels has not been irrigated since 1979; however, volunteer vegetation, including the remains of previous alfalfa crops, grew in the cultivated area by obtaining water from the shallow water table. In this area, phreatophytes consume ground water.

In 1983, the Federal government instituted the PIK (Payment-InKind) Program in which cotton growers were subsidized for not planting as much as half their usual cotton acreage. The PIK Program extended into 1984 but affected less acreage than in 1983. Cotton is grown only in Cibola Valley Irrigation and Drainage District and volunteer vegetation grew in many of the fields left fallow during the PIK Program. 
In 1984, almost all the fields in Cibola Valley Irrigation and Drainage District were plowed over; most were replanted with new crops but some remained fallow. About 300 acres of land were cleared of phreatophytes and added to the cultivated area. As a result of the increase in cultivated area from 1983 to 1984, diversions from the river increased because the total cropped area increased about 400 acres (fig. 4). The 400 acres consist of the 300 acres of new cultivated area and the replanting of 100 acres that were fallow in 1983 from the PIK Program. From 1983 to 1984, the areas of different crop types varied. Cotton and other crops mainly bermuda, pasture grasses, and milo-increased, whereas alfalfa and grains decreased. Fallow areas decreased from 1983 to 1984. No multiple cropping was reported for Cibola Valley.

Vegetated area includes the cropped area and the area of phreatophytes. Principal phreatophytes in Cibola Valley are saltcedar and mesquite (Anderson and Ohmart, 1976). Phreatophytes covered 68 and 61 percent of the vegetated area in 1983 and 1984 , respectively (table 1 ). The 7-percent decrease in phreatophytes from 1983 to 1984 occurred because sustained water levels above the land surface drowned some phreatophytes. Areas of dead phreatophytes were mapped from aerial photographs taken in August 1985.

\section{Consumptive-Use Terminology}

In Cibola Valley, water is used mainly for agriculture. Water also is consumptively used by phreatophytes and as a domestic and municipal supply. Water diverted from the river is applied to crops. Some of the diverted water is consumptively used by crops and some percolates to the water table where it is consumptively used by phreatophytes, discharges into the drainage ditch or the river, or flows as ground water across the east flood-plain boundary and into the terraces. Water use by crops and phreatophytes is collectively referred to as water use by vegetation.

An estimate of consumptive use by vegetation for that part of the valley drained by the river is needed in order to estimate ground-water return flow. The results of each of three methods of estimating water use were given different terms to distinguish one from another and for the purpose of comparison within Palo Verde Valley (Owen-Joyce and Kimsey, 1987) and Parker Valley (Owen-Joyce, 1988). That terminology is maintained in this report even though consumptive use by vegetation cannot be estimated with a water budget because in no part of the valley are return flows captured by drainage ditches. The following describes the modification to the water-budget method that was used to estimate consumptive use by vegetation in Palo Verde and Parker Valleys for use in Cibola Valley.

Consumptive use by vegetation is the loss of water from an area through evapotranspiration and through evaporation from bare-soil (nonvegetated areas or fallow irrigated fields) and open-water surfaces (excluding the river). In a previous study (Owen-Joyce, 1984, p. 41), consumptive use by vegetation in Cibola Valley was estimated by adjusting evapotranspiration by vegetation to include evaporation by open-water and bare-soil surfaces using the relation between the two values determined for 


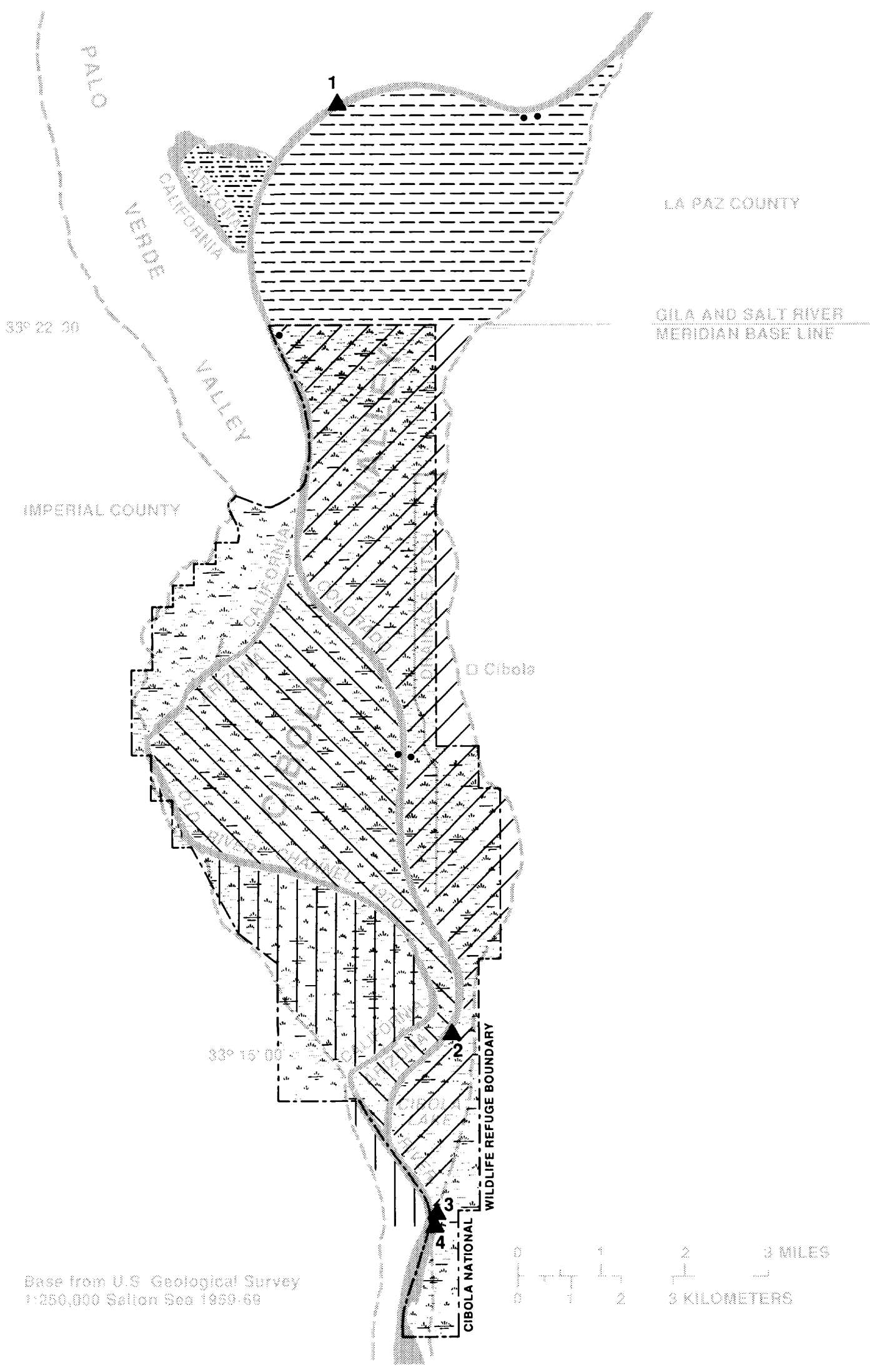

Figure 2.--Cibola Valley and location of streamflow-gaging stations and surface-water measurement sites. 
E X P L A N A T I O N

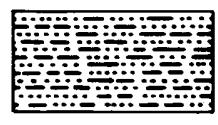

ARIZONA LAND ON THE CALIFORNIA SIDE OF THE COLORADO RIVER IRRIGATED WITH WATER DIVERTED FROM THE RIVER AT PALO VERDE DAM

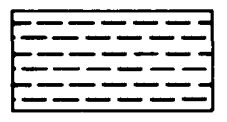

CIBOLA VALLEY IRRIGATION AND DRAINAGE DISTRICT

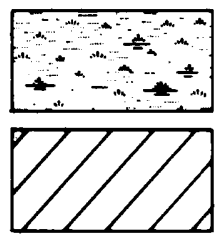

CIBOLA NATIONAL WILDLIFE REFUGE

ARIZONA LAND SOUTH OF THE GILA AND SALT RIVER MERIDIAN BASE LINE AND EAST OF THE COLORADO RIVER

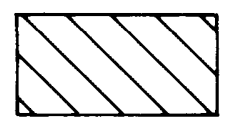

ARIZONA LAND BETWEEN THE OLD AND NEW COLORADO RIVER CHANNELS

CALIFORNIA LAND WEST OF THE OLD CHANNEL AND NORTH OF THE SOUTHERNMOST GAGING STATION

COLORADO RIVER FLOOD-PLAIN BOUNDARY

RIVER PUMP(S)

CONTINUOUS-RECORD STREAMFLOW GAGING STATIONNumber, 2, corresponds to station names listed below

\section{Index of gaging stations}

1. Colorado River at Cibola Cross Section No. 28

2. Cibola Lake inlet near Cibola

3. Cibola Lake outlet near Cibola

4. Colorado River below Cibola Valley

Colorado River below Parker Dam-Gaging station located 96.1 miles upstream from Colorado River below Cibola Valley (this station does not have a number because it is located outside the map area) 


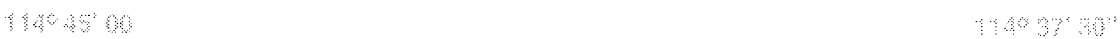

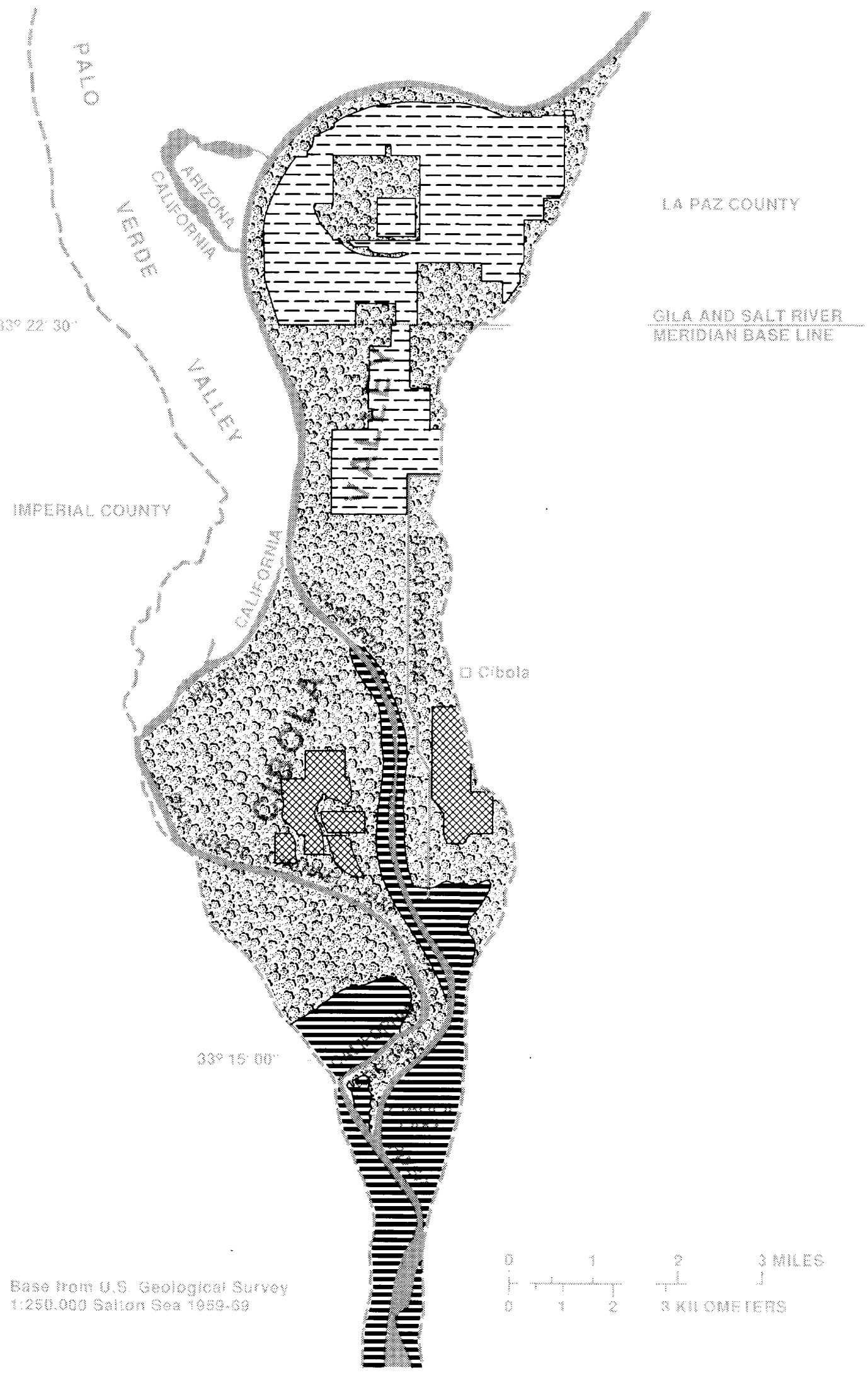

Figure 3.--Cultivated land and phreatophyte areas in Cibola Valley, Arizona. 
E X P L A N A T I O N

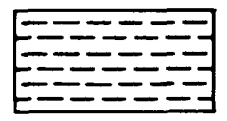

LAND IRRIGATED WITH WATER PUMPED FROM THE COLORADO RIVER AT VARIOUS SITES

LAND NOT IRRIGATED IN 1983 AND 1984

AREA OF PHREATOPHYTES

AREA WHERE MORE THAN 50 PERCENT OF THE PHREATOPHYTES DIED BECAUSE OF GROUND-WATER LEVELS AT OR NEAR THE LAND SURFACE

COLORADO RIVER FLOOD-PLAIN BOUNDARY 


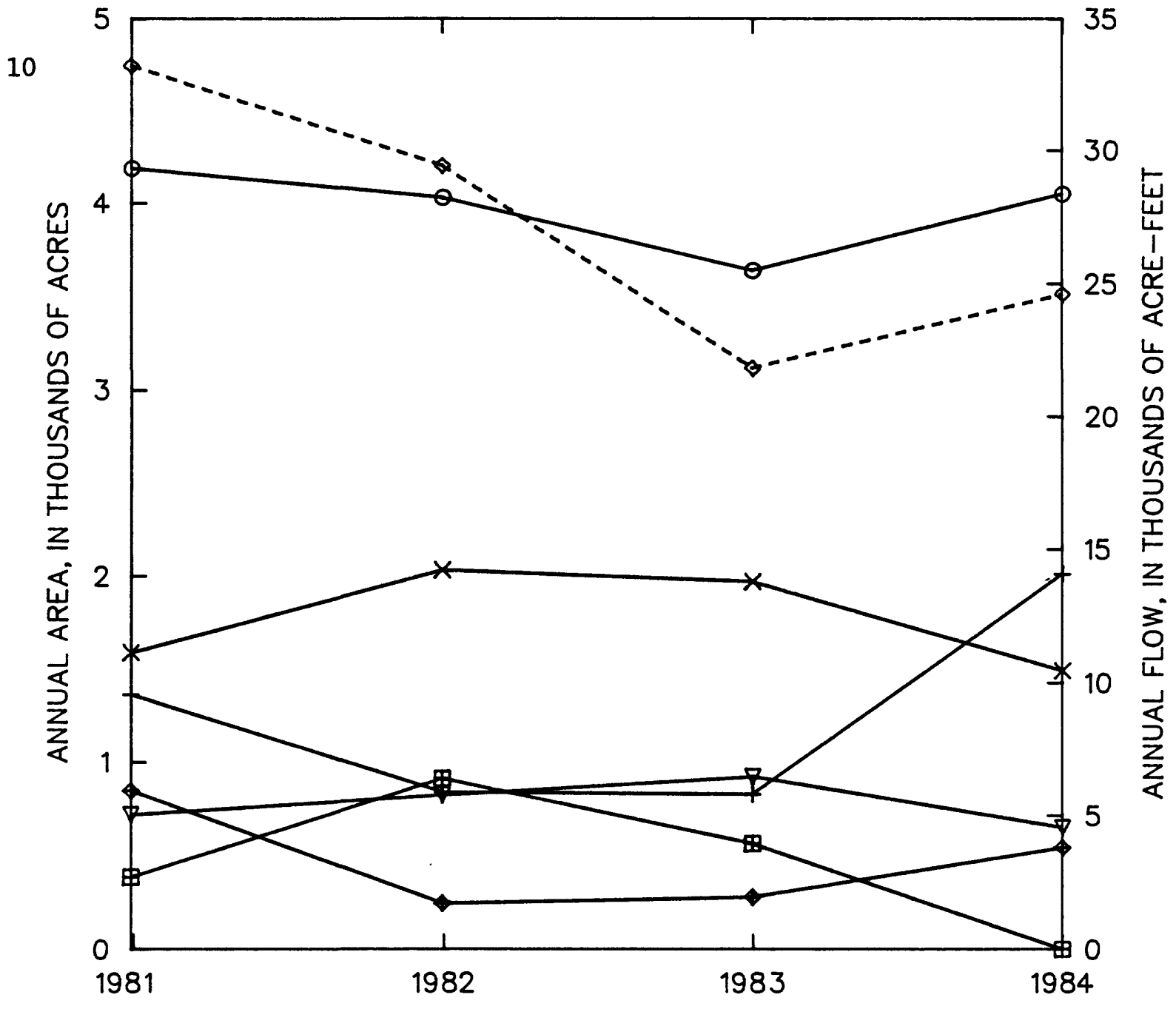

EXPLANATION

FLOW

$\diamond \ldots-\downarrow$ Diverted irrigation water

AREA

$\circlearrowleft$ Cropped area

$\longleftarrow$ Alfalfo

$\longrightarrow$ Cotton

$\longmapsto$ Fallow

$\boxplus$ Grains

$\longrightarrow$ Other crops

Figure 4.--Annual acreages by crop type, total cropped area, and diversions in Cibola Valley, Arizona, 1981-84. 
Tablo 1. - Estimates of evapotranspiration by vegetation in Cibola Valley, Arizona and California, 1983-84

\begin{tabular}{|c|c|c|c|c|c|c|c|c|c|c|}
\hline \multirow[b]{3}{*}{$\begin{array}{l}\text { Vegeta- } \\
\text { tion } \\
\text { type }\end{array}$} & \multirow[b]{3}{*}{$\begin{array}{c}\mathrm{ET}^{1}, \\
\text { in } \\
\text { feet }\end{array}$} & \multicolumn{4}{|c|}{ East of Colorado River } & \multicolumn{5}{|c|}{ West of Colorado River } \\
\hline & & \multicolumn{2}{|c|}{ North of base line 2} & \multicolumn{2}{|c|}{ South of base line } & \multirow{2}{*}{$\begin{array}{c}\text { Between } \\
\begin{array}{c}\text { Area, } \\
\text { in } \\
\text { acres }\end{array}\end{array}$} & \multirow{2}{*}{ old } & \multirow{2}{*}{$\begin{array}{c}\text { and new channels } \\
\text { ET, } \\
\text { in } \\
\text { acre-feet }\end{array}$} & \multicolumn{2}{|c|}{ In California } \\
\hline & & $\begin{array}{l}\text { Area, } \\
\text { in } \\
\text { acres }\end{array}$ & $\begin{array}{c}\text { ET, } \\
\text { in } \\
\text { acro-feet }\end{array}$ & $\begin{array}{l}\text { Area, } \\
\text { in } \\
\text { acres }\end{array}$ & $\begin{array}{c}\text { ET, } \\
\text { in } \\
\text { acre-feet }\end{array}$ & & & & $\begin{array}{l}\text { Area, } \\
\text { in } \\
\text { acres }\end{array}$ & $\begin{array}{c}\text { ET, } \\
\text { in } \\
\text { acre-feet }\end{array}$ \\
\hline \multicolumn{11}{|c|}{1983} \\
\hline Alfalfa & 36.7 & 870 & 5,829 & 1,100 & 7,370 & 0 & & $-\cdots$ & 0 & $-\cdots$ \\
\hline Cotton & 3.7 & 827 & 3,060 & 0 & - & 0 & & - - - & 0 & $\cdots$ \\
\hline Grain & 3.4 & 459 & 1,102 & 106 & 254 & 0 & & - - & 0 & $-\cdots$ \\
\hline Other & 4.0 & 124 & 496 & 156 & 624 & $\underline{0}$ & & $m-\cdots$ & $\underline{0}$ & $m$ \\
\hline Subtotal & & 2,280 & 10,487 & 1,362 & 8,248 & 0 & & $-\cdots-$ & 0 & $\cdots$ \\
\hline $\begin{array}{c}\text { Phreato- } \\
\text { phytes }\end{array}$ & 53.4 & 1.983 & 6.742 & $\underline{5.659}$ & 19,241 & 4.756 & & 16.170 & $\underline{2.720}$ & 9.248 \\
\hline \multicolumn{2}{|c|}{ Total (rounded) } & 4,263 & 17,200 & 7,021 & 27,500 & 4,756 & & 16,200 & 2,720 & 9,200 \\
\hline \multicolumn{11}{|c|}{1984} \\
\hline Alfalfa & 36.8 & 679 & 4,617 & 816 & 5,549 & 0 & & $-\cdots$ & 0 & $-\cdots$ \\
\hline Cotton & 3.7 & 2,011 & 7,441 & 0 & $\cdots$ & 0 & & - & 0 & $\cdots-$ \\
\hline Grain & 32.4 & 0 & $\cdots-\cdots$ & 0 & $\cdots-$ & 0 & & $\cdots-\cdots$ & 0 & $\cdots-$ \\
\hline Other & 4.2 & 261 & 836 & 282 & 902 & $\underline{0}$ & & $=-\cdots$ & $\underline{0}$ & $=-\cdots$ \\
\hline Subtotal & & 2,951 & 12,894 & 1,098 & 6,451 & 0 & & $-\cdots-$ & 0 & $-\cdots$ \\
\hline $\begin{array}{l}\text { Phreato- } \\
\text { phytes }\end{array}$ & 53.4 & 1.983 & 6.742 & 4.242 & 14,423 & 4,756 & & 16.170 & 1.745 & $\underline{5.933}$ \\
\hline Total (ro) & anded) & 4,934 & 19,600 & 5,340 & 20,900 & 4,756 & & 16,200 & 1,745 & 5,900 \\
\hline
\end{tabular}

$1_{\text {ET, Evapotranspiration. }}$

2Cibola Valley Irrigation and Drainage District.

Botermined using Blaney-Criddle equation (Blaney and Criddle, 1950) and temperature data for Ehrenberg, Arizona.

${ }^{4}$ Calculated as an area-weighted average of Blaney-Criddle determined evapotranspiration for other crops.

5oyle Engineering Corp. (1976, p. II-7). 
Palo Verde Valley (Owen-Joyce, 1984). Consumptive use by vegetation may be expressed as

$$
C U v_{r}=F(E T)
$$

where

$$
\begin{aligned}
C U v_{r} & =\text { estimated consumptive use by vegetation, in acre-feet, } \\
& \text { in the area drained by the river; } \\
F & =\text { the ratio between consumptive use by vegetation and } \\
& \text { evapotranspiration in Palo Verde Valley; and } \\
E T & =\text { estimated evapotranspiration, in acre-feet. }
\end{aligned}
$$

Palo Verde Valley is northwest and across the river from Cibola Valley, and the percentage difference between consumptive use by vegetation and evapotranspiration in 1981 was assumed to be transferable for use in Cibola Valley.

Evapotranspiration is the loss of water from a land area through transpiration by vegetation and through evaporation from the soil surface under the vegetation. Evapotranspiration may be expressed as

$$
E T=\Sigma(A \times W u)
$$

where

$$
\begin{aligned}
A & =\text { the area, in acres, of each vegetation type; and } \\
W u & =\text { water-use rate, in feet, for that vegetation type. }
\end{aligned}
$$

Consumptive use of Colorado River water is the loss of water from the Colorado River as defined by the decree (U.S. Supreme Court, 1964) and may be expressed as

$$
C U_{C r}=S W D-S W R F-G W R F
$$

where

$$
\begin{aligned}
C U_{C r}= & \text { estimated consumptive use, in acre-feet, of Colorado } \\
& \text { River water; } \\
S W D= & \text { measured surface-water diversion, in acre-feet, from } \\
& \text { the river; } \\
S W R F= & \text { measured surface-water return flow, in acre-feet, to } \\
& \text { the Colorado River from the drainage ditch; and } \\
G W R F= & \text { estimated ground-water return flow, in acre-feet, to } \\
& \text { the river. }
\end{aligned}
$$


Ground-water return flow is estimated from a water budget for that part of the shallow alluvial aquifer drained by the river (Owen-Joyce and Kimsey, 1987, p. 41) and may be expressed as

$$
G W R F=S W D_{r}+P_{\text {eff }}-C U v_{r}-\Delta S_{r}
$$

where

$$
\begin{aligned}
S W D_{r}= & \text { that part of the measured surface-water diversion, in } \\
& \text { acre-feet, from the river applied to irrigated land in } \\
& \text { the area drained by the river; } \\
P_{e f f}= & \text { effective precipitation, in acre-feet; and } \\
\Delta S_{r}= & \text { change in ground-water storage, in acre-feet, in the } \\
& \text { shallow alluvial aquifer in the area drained by the } \\
& \text { river. }
\end{aligned}
$$

\section{Acknowledgments}

Wayne Sprawls of the Cibola Valley Irrigation and Drainage District provided agricultural data, including crop types and acreages by crop type.

\section{HYDROLOGIC SYSTEM}

The hydrologic system in Cibola Valley includes the highly regulated Colorado River and a shallow alluvial aquifer that underlies the flood plain. River water is pumped into a system of concrete-lined canals for application to fields on the flood plain. Deep percolation of irrigation water causes mounding of the water table under the fields in the northern part of the valley and creates a ground-water divide. Ground water on the northwest side of the divide drains to the river as groundwater return flow; water on the southeast side moves away from the divide into areas of phreatophytes, into the drainage ditch, and out of the flood plain into the bordering terraces. In the southern part of the valley, the river loses water directly to the aquifer through seepage, and ground water moves away from the river (Owen-Joyce, 1984, p. 8). Some ground water may discharge from the alluvial aquifer to an underlying aquifer. Changes in stage of the Colorado River and agricultural development affect saturated thickness and the direction of ground-water movement in the alluvial aquifer.

The Colorado River, shallow aquifer, and drainage ditch are hydraulically connected. When flow in the river is regulated for downstream requirements, most of the river reach adjacent to irrigated land in the northern part of the valley gains water from the aquifer. The river reach adjacent to large areas of phreatophytes and irrigated areas in the southern part of the valley loses water to the aquifer (Owen-Joyce, 1984, p. 8). During years when the river stage rises or is sustained at high 
levels because of flood-control releases, almost the entire reach of the river in Cibola Valley loses water to the aquifer. Short reaches associated with large bends in the river, such as near the intersection with the Gila and Salt River meridian base line, gain water from the aquifer.

Ground water occurs under water-table conditions in the alluvium. In 1983 and 1984, the depth to water measured in shallow (less than $35 \mathrm{ft}$ deep) observation wells on the flood plain ranged from about $1 \mathrm{ft}$ above the land surface to $14 \mathrm{ft}$ below the land surface. Access to many of the wells in the southern part of the valley was restricted because surface roads were flooded as a result of the water table being above the land surface. Some of the fields and areas of phreatophytes between the old and new river channels were flooded where the water table rose and stayed above the land surface.

The alluvium has been divided into the younger alluvium and older alluviums. The younger alluvium forms the flood plain of the Colorado River; the older alluviums form the terraces and alluvial slopes that bound the flood plain (Metzger and others, 1973). Near Cibola, the older alluviums are not present in the subsurface; the younger alluvium lies directly on the Bouse Formation of late Tertiary age.

The Bouse Formation is an estuarine deposit composed of limestone, clay, silt, sand, and tufa (Metzger, 1968, p. 126). The upper zone of the Bouse Formation is composed mainly of sand, which is hydraulically connected to the alluvium and transmits water. The lower zone is mainly clay, which makes up as much as 50 percent of the formation and is a confining bed (Metzger and Loeltz, 1973, p. 19). This confining bed retards the vertical flow of water between the underlying fanglomerate and the overlying alluvium. The fanglomerate is an artesian aquifer composed chiefly of cemented gravel (Metzger, 1965, p. 203).

\section{Colorado River}

Flow in the Colorado River is controlled by Parker Dam, which is about $86 \mathrm{mi}$ upstream from the north end of Cibola Valley (fig. 1). Releases at Parker Dam satisfy downstream water and flood-control requirements. Annual releases at Parker Dam ranged from 6.3 to 20.5 milion acre-ft from 1960 to 1984 (fig. 5). Annual flow in the Colorado River below Cibola Valley (fig. 2, site 4) ranged from 5.5 to 19.1 million acre-ft from 1960 to 1984 ( $f i g .5$ ). The decrease in flow between Parker Dam and the Colorado River below Cibola Valley gage indicates the diversion and consumptive use of Colorado River water in Parker, Palo Verde, and Cibola Valleys (fig. 1).

When releases at Parker Dam satisfy downstream requirements, flow in the Colorado River varies seasonally and is highest in summer when irrigation needs are greatest (see 1982 in fig. 6). Daily flows below Cibola Valley are less than those below Parker Dam but follow the same trend (figs. 6 and 7). Releases of water from reservoir storage for irrigation and power generation, diversions, evapotranspiration, and spillage from canals and return flows to the river between the gages below 


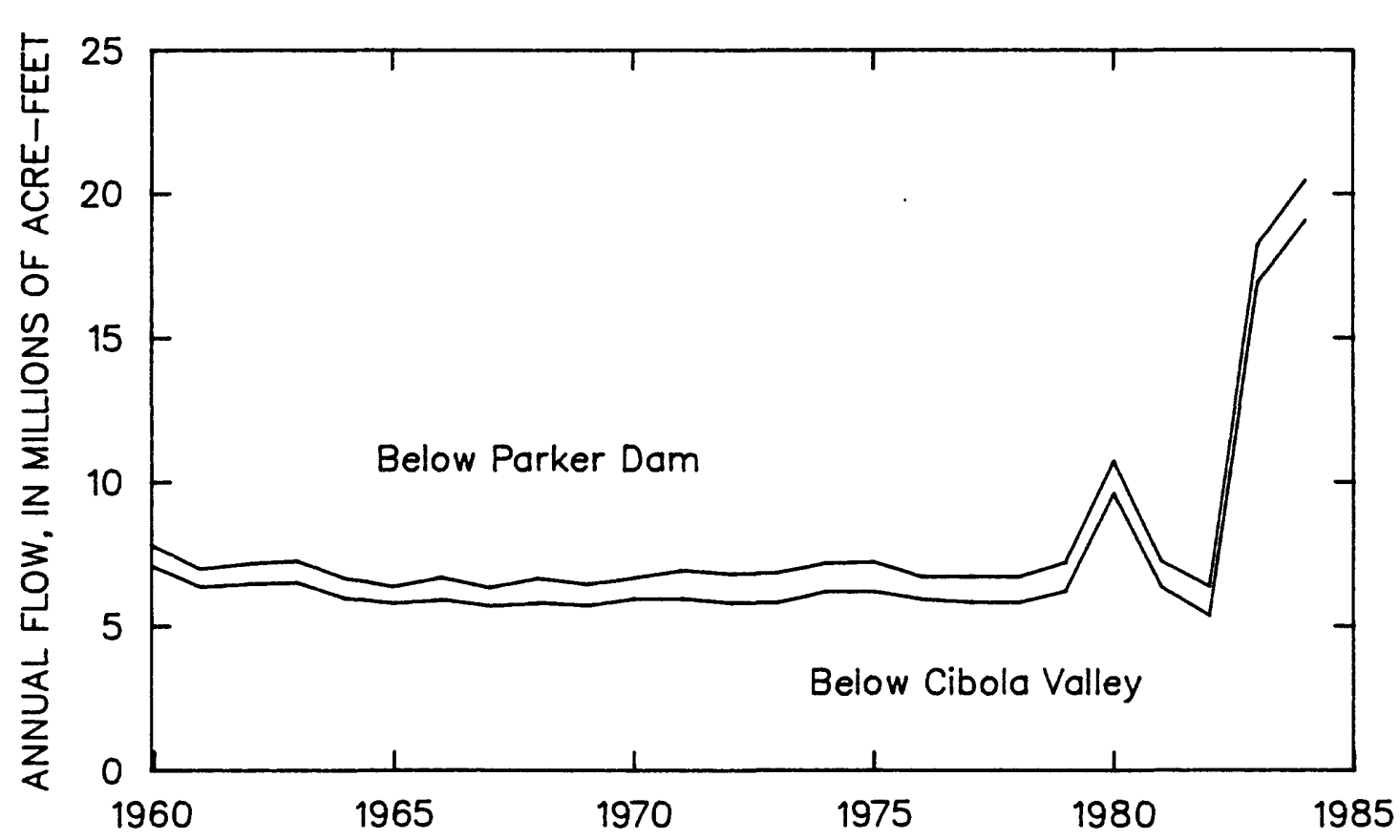

Figure 5.--Annual flow in the Colorado River, 1960-84.

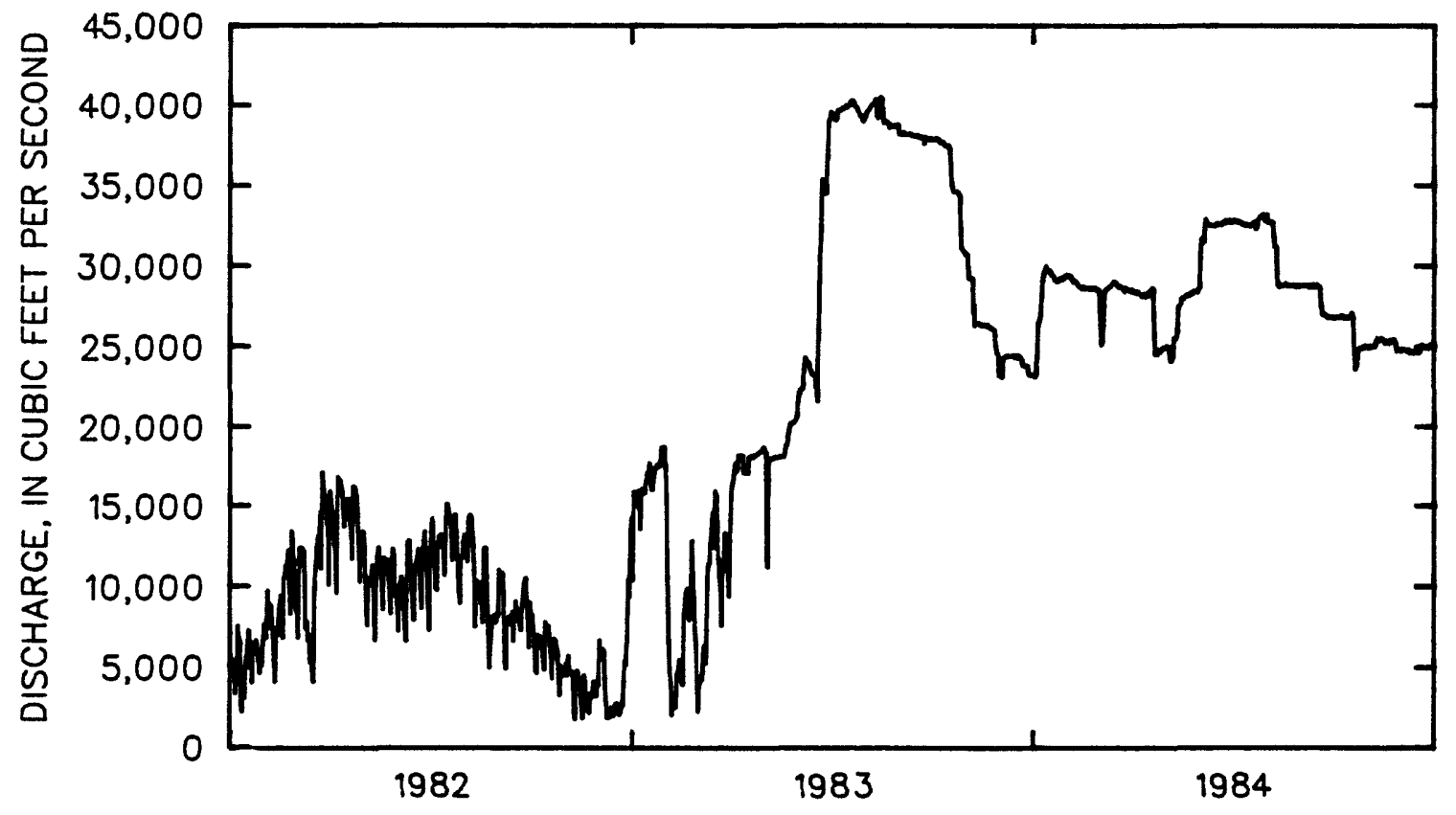

Figure 6.--Daily mean flow in the Colorado River below Parker Dam, 1982-84. 


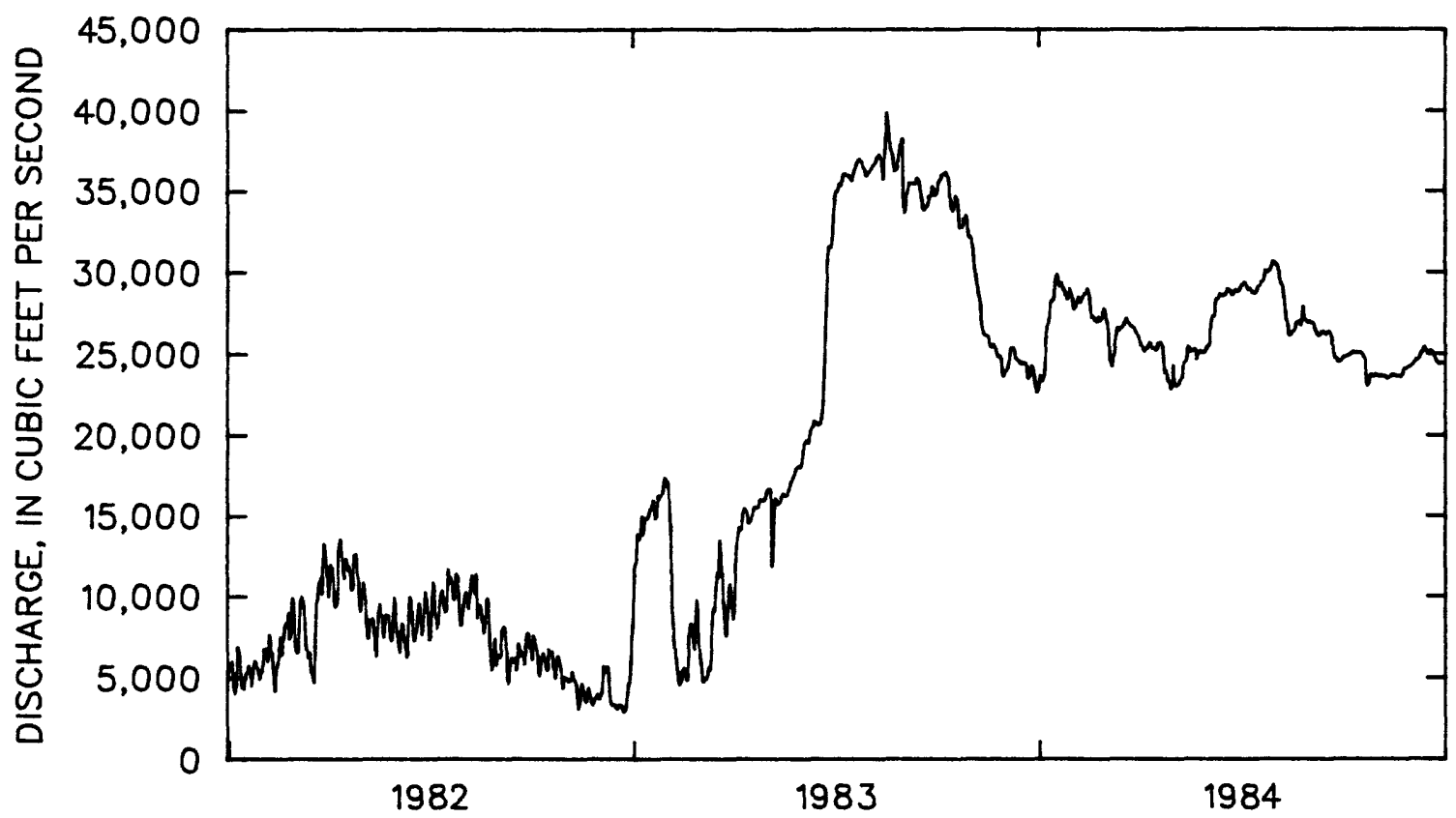

Figure 7.--Daily mean flow in the Colorado River below Cibola Valley, 1982-84.

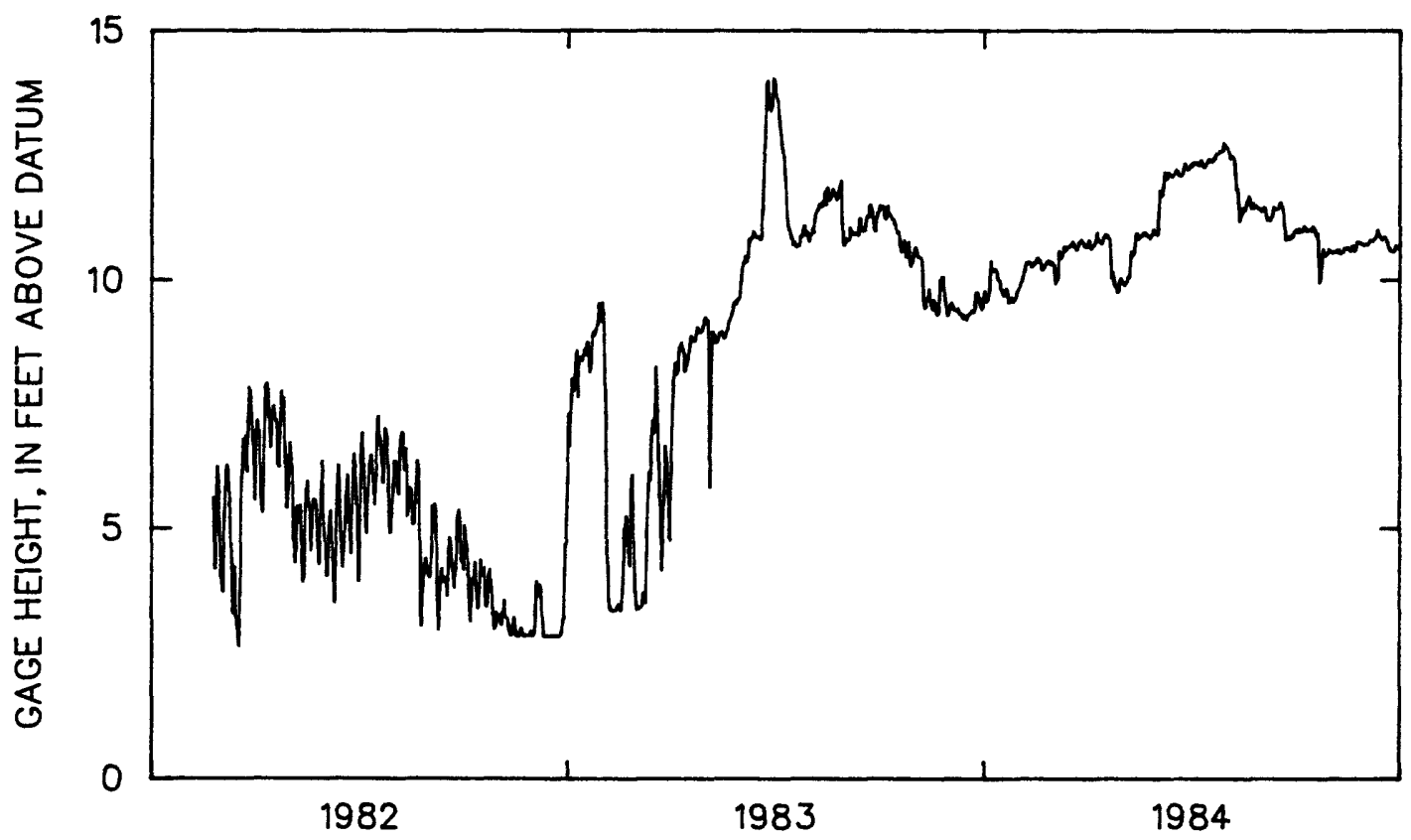

Figure 8.--Daily mean gage height of the Colorado River at Cibola Cross Section No. 28, 1982-84. 
Parker Dam and below Cibola Valley contribute to daily fluctuations in flow. Flood-control releases dominated the flow pattern in 1983 and 1984, and the normal seasonal variations did not occur.

Changes in stage of the Colorado River cause fluctuations in ground-water levels beneath the flood plain and in the quantity of ground water in storage. River stage was from 5 to $10 \mathrm{ft}$ higher in 1983 and 1984 than in 1982 (fig. 8) as measured at a river stage gage installed at Cibola Cross Section No. 28 (fig. 2, site 1). Cross sections are data-collection sites, each of which has 12 piezometers; some of the cross sections include a river stage gage. (See section entitled "Ground Water" for a brief explanation or see Loeltz and Leake, 1983, p. 25-29 for a detailed explanation.)

\section{Diversions and Surface-Water Return Flow}

Water can be pumped from the Colorado River at five pump sites by water users in Cibola Valley (fig. 2). Water users pumped 21,800 acre-ft of water in 1983 and 24,600 acre-ft in 1984 (table 2).

Table 2. - Diversions to Cibola Valley. Arizona. 1983-84. in acre-feet per year

11983

21984

Water user:

Cibola Valley Irrigation and Drainage District 12,145 15,580

Sprawl, Wayne $3,180 \quad 3,600$

Cibola National Wildife Refuge 6.502 5,434 Total (rounded) 21,800 24,600

${ }^{1}$ U.S. Bureau of Reclamation, 1985, p. 7 and 12.

${ }^{2}$ U.S. Bureau of Reclamation, 1986, p. 7 and 12.

Surface-water return flow includes water that spills from canals, laterals, and wasteways and ground water that returns to the river in openchannel drainage ditches. In Cibola Valley, no water spills back to the river, and the only drainage ditch in the valley does not act as a drain. The ditch is not gaged because it does not return water to the river; it empties into the marsh lands north of Cibola Lake.

Cibola Lake is at the south end of Cibola Valley. When flow in the river is regulated for downstream requirements, water flows into the lake through a controlled inlet and is gaged (fig. 2, site 2). Water 
returns to the river through Cibola Lake outlet and is gaged (fig. 2, site 3). However, during 1983 and 1984, Cibola Lake inlet and outlet gages were not operational because the high river stage caused inundation of both gages.

\section{Precipitation}

Precipitation provides a small quantity of water, some of which is available for consumptive use by vegetation. Precipitation is considered to be a source of recharge to the aquifer when the mean annual precipitation exceeds 8 in. (Metzger and Loeltz, 1973, p. 35). Annual precipitation at Ehrenberg, Arizona, about $15 \mathrm{mi}$ northeast of Cibola Valley, ranged from 0.14 to 8.76 in. between 1941 and 1984 (fig. 9); mean annual precipitation was 4.11 in. About one-third of the precipitation occurs from May to September.

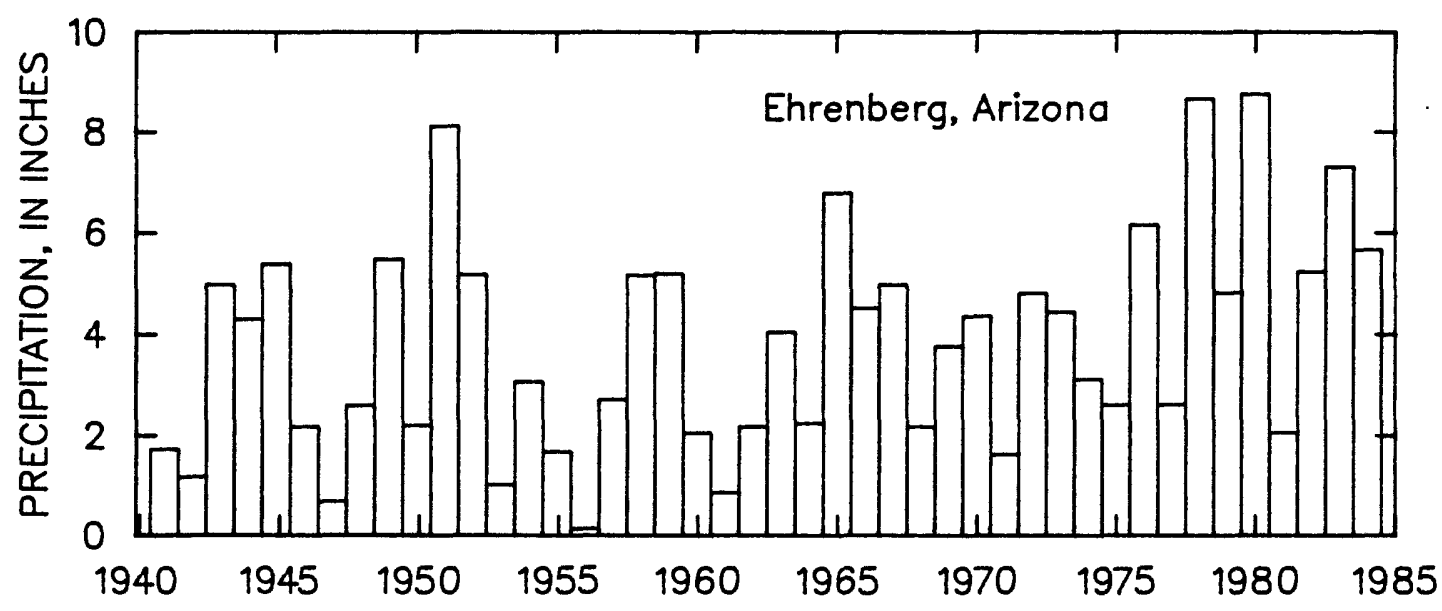

Figure 9.--Annual precipitation at Ehrenberg, Arizona, 1941-84.

Effective precipitation was used as a measure of the quantity of precipitation available for consumptive use by vegetation. Estimates of annual effective precipitation were made by summing rainfall that was in excess of 0.25 in. per storm (U.S. Bureau of Reclamation, Lower Colorado River Region, Yuma Project office, oral commun., 1986) to determine the amount of precipitation available to vegetation that could affect the consumptive use of Colorado River water. Effective precipitation may be expressed as

$$
P_{\text {eff }}=P_{\text {eff }}\left(A_{c}+A_{p}\right),
$$




$$
\begin{aligned}
P_{\text {eff }} & =\text { effective precipitation, in acre-feet; } \\
P_{\text {eff }} & =\text { annual effective precipitation, in feet; } \\
A_{c} & \text { - cultivated area, in acres; and } \\
A_{p} & =\text { the area, in acres, of phreatophytes. }
\end{aligned}
$$

Annual effective precipitation may be expressed as

$$
P_{\text {eff }}=\Sigma\left(\frac{R F_{0}}{12} \cdot \frac{25}{-}\right)
$$

where

$$
\begin{aligned}
R F_{0.25} & =\text { effective rainfall per storm, in inches } \\
& =\left(\begin{array}{cl}
R F-0.25 & \text { if } R F>0.25 \\
0 & \text { if } R F<0.25
\end{array}\right.
\end{aligned}
$$

and

$$
R F \text { = total rainfall per storm, in inches. }
$$

Annual effective precipitation from 1980 to 1984 (table 3) was computed from weather records for Ehrenberg, Arizona (National Climatic Data Center, 1980-84). Effective precipitation was estimated to be 45,700 acre-ft in 1983 and 11,600 in 1984.

Table 3.--Annual precipitation for Ehrenberg. Arizona, 1980-84, in inches

\begin{tabular}{ccc}
\hline & \multicolumn{2}{c}{ Precipitation } \\
\cline { 2 - 3 } Year & Effective & Total \\
\hline 1980 & 6.73 & 8.76 \\
1981 & 0.32 & 2.06 \\
1982 & 2.38 & 5.23 \\
1983 & 4.05 & 7.31 \\
1984 & 1.13 & 1.62 \\
\hline
\end{tabular}




\section{Ground Water}

East of the Colorado River, Cibola Valley was divided into two ground-water drainage areas by delineating the area under which ground water drains to the river and the area under which ground water drains away from the river. The two areas are separated by a ground-water divide. In 1981, the ground-water divide was under the irrigated land in the northern part of the valley but trended southwest to intersect the river. From the intersection southward to the southernmost gaging station, the river forms the ground-water divide (Owen-Joyce, 1984, fig. 11). Where ground water flows away from the river, it flows into areas of phreatophytes, to the drainage ditch, and out of the flood plain into the terraces (Owen-Joyce, 1984 , p. 35).

The area under which ground water drains to the river was delineated in order to estimate ground-water return flow to the Colorado River. Contours of annual average water-table altitudes were used to determine the location of a ground-water divide that delineates the two ground-water drainage areas (Owen-Joyce, 1984, p. 18). Annual average water-table altitudes were determined by averaging monthly water levels in shallow observation wells and piezometers. Land-surface altitudes at the well sites were obtained by differential leveling by the U.S. Bureau of Reclamation. Water-level data were not available for the drainage ditch.

Piezometers, or small-diameter wells, were installed at $12 \mathrm{sam}$ pling points within each of nine cross sections adjacent to the river in Cibola Valley. Cross sections are lines normal to the river that extend about $500 \mathrm{ft}$ on each side of the river and are about $1 \mathrm{mi}$ apart along the river (see fig. 10 for location of cross sections; cross sections adjacent to Cibola Valley are numbered X25-X33). Each piezometer within a cross section is referenced with $A Z$ or $C A$ followed by a single digit from 1 to 6 . $\mathrm{AZ}$ indicates that the sampling point is on the Arizona side of the river and $C A$ indicates the California side of the river. The digits 1, 2, and 3 indicate the shallow, medium, and deep locations, respectively, about $100 \mathrm{ft}$ from the river. The digits 4, 5, and 6 indicate the shallow, medium, and deep locations, respectively, about $500 \mathrm{ft}$ from the river. Piezometers $100 \mathrm{ft}$ from the river are referred to as near-cluster piezometers and those about $500 \mathrm{ft}$ from the river as far-cluster piezometers. During this study, water levels in the shallow piezometers in the near and far clusters ( $A Z 1, A Z 4, C A 1$, and CA4) were measured monthly along with the shallow observation wells distributed throughout the valley. Water levels measured in the piezometers provided data for contouring the water-table surface near the river.

From year to year, the ground-water divide was found to move in response to changes in river stage and application of irrigation water. Water-table contours for 1983 (fig. 10) and 1984 (fig. 11) indicate that in most of Cibola Valley ground water flowed away from the river. Application of irrigation water to fields in Cibola Valley Irrigation and Drainage District in 1983 and 1984 caused a partial mound to form under the fields, but water levels did not rise enough to overcome the gradient from the river (figs. 10 and 11). Ground water flowed westward toward the river from the mound during both years but did not return to the river. In 1983 , flood-control releases at Parker Dam (fig. 6) caused rising river stage during the first half of the year and sustained high river stage during the 
second half (fig. 8), which resulted in the river losing water to the alluvial aquifer. In 1984, releases from Parker Dam remained higher than downstream requirements but were lower than releases in 1983 ( $\mathrm{fig} .6$ ). River stage adjacent to Cibola Valley remained near 1983 levels (fig. 8). Because of sustained high river stage, most of the river continued to lose water to the aquifer in 1984 .

Average annual water levels in the near- and far-cluster shallow piezometers at cross sections X26, X27, X28, and X33 were about 1 ft higher than water levels in the observations wells on the Arizona side of the river. These data indicated that ground-water movement was away from the river. Average annual water leve1s at cross sections X29-X32 were at least $1 \mathrm{ft}$ lower than in nearby observation we11s and indicate that ground-water flow was toward the river. Average annual water levels between we11s AZ1 and AZ4 (table 4) indicate gradients of less than $\pm 6 \mathrm{ft} / \mathrm{mi}$ and variable flow directions within $500 \mathrm{ft}$ of the river. Variations in mean daily river stage of more than $1 \mathrm{ft}$ cause similar changes in the water levels of the highly responsive alluvial aquifer.

Table 4. - Average annual water-table altitudes in the sha1low piezometers and change in head between the near- and far-cluster shallow piezometers along the Colorado River adjacent to Cibola Valley, Arizona, 1983-84

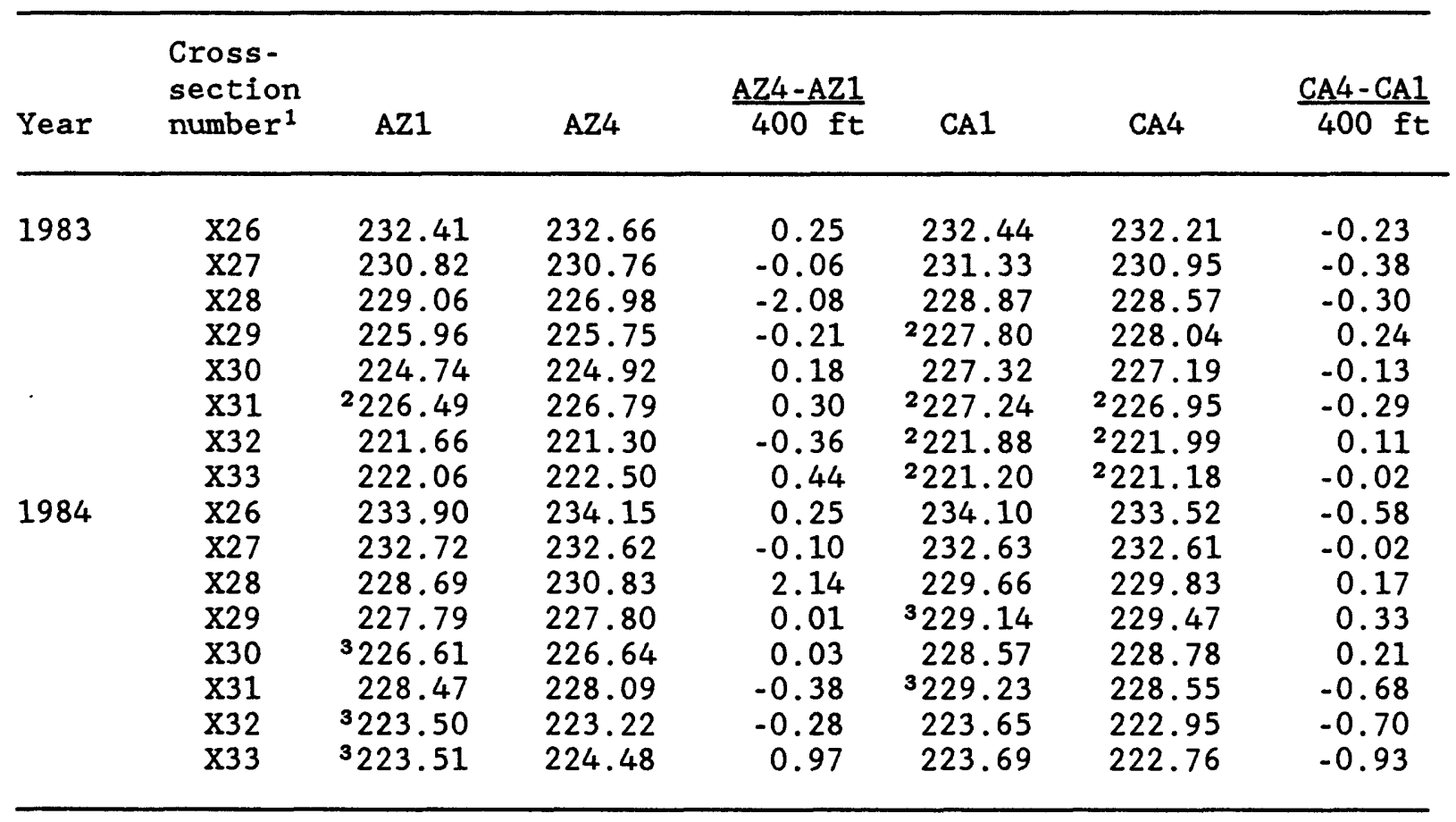
and 11 .

${ }^{1}$ Cross-section number corresponds to locations plotted on figures 10

${ }^{2}$ We11s in which less than 11 months were averaged. Water levels were available for 11 months in 1983; no water levels were measured in June. Access to some of the wells was not possible some months because the water table was above the land surface.

${ }^{3} \mathrm{We} 11 \mathrm{~s}$ in which less than 12 months were averaged. Water leve1s were available for 12 months in 1984. 


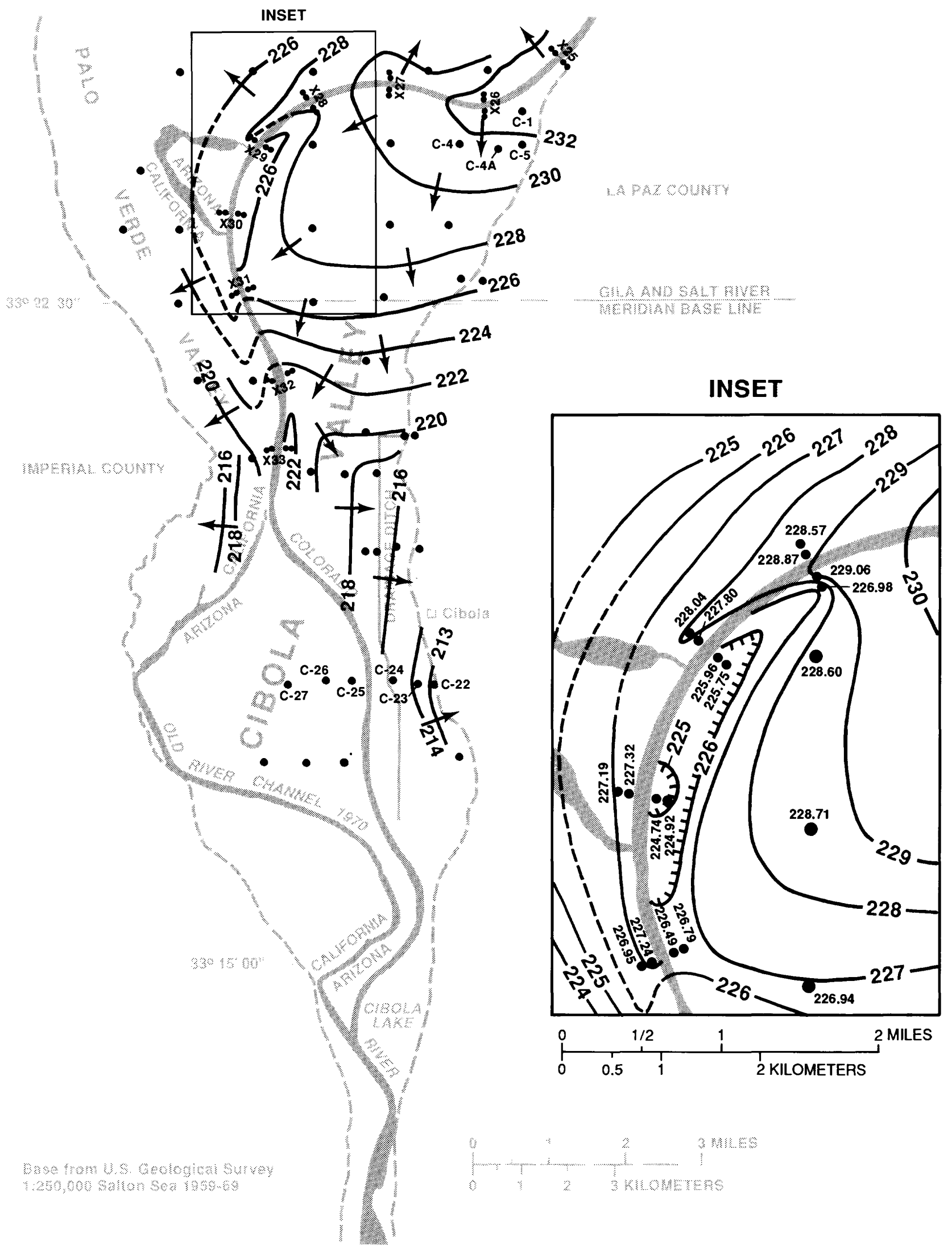

Figure 10.--Average water-table altitude in Cibola Valley, Arizona and California, 1983. 
E X P L A N A T I O N

WATER-TABLE CONTOUR-Shows average altitude of water table, 1983. Dashed where approximately located. Contour interval 2 feet. Contour interval 1 foot on inset map. Datum is sea level

COLORADO RIVER FLOOD-PLAIN BOUNDARY

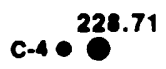

SHALLOW OBSERVATION WELL OR PIEZOMETER-Number, $\mathrm{C} 4$, is a well number that corresponds to the hydrographs on figures 14 and 15 . Number, 228.71 , average altitude of water table on inset map

$x_{\infty}^{x+\infty}$

CROSS SECTION-Number, $X 31$, is a cross section that corresponds to table 4

DIRECTION OF GROUND-WATER MOVEMENT 


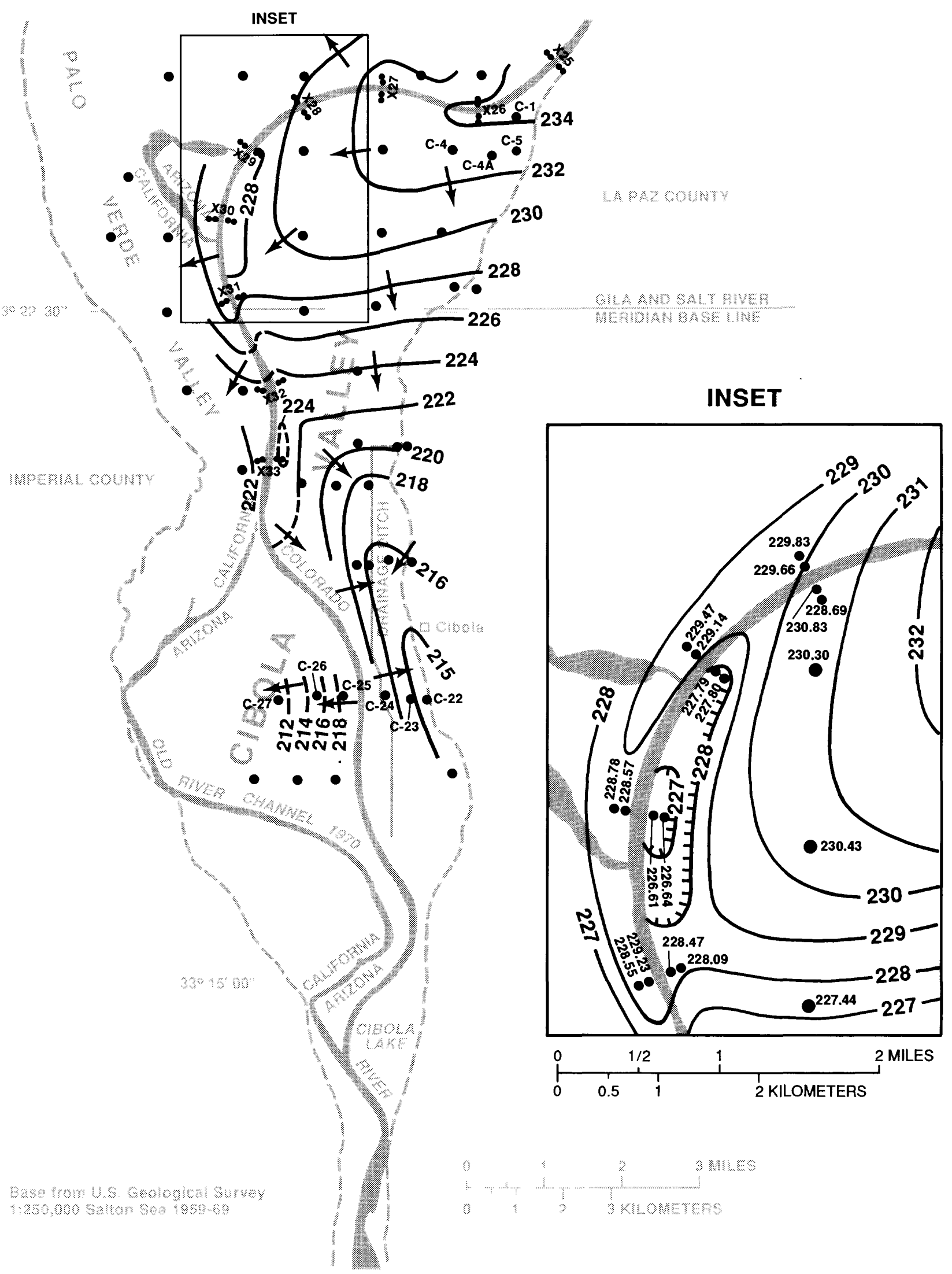

Figure 11.--Average water-table altitude in Cibola Valley, Arizona and California, 1984. 
EX P L A N A T I O N

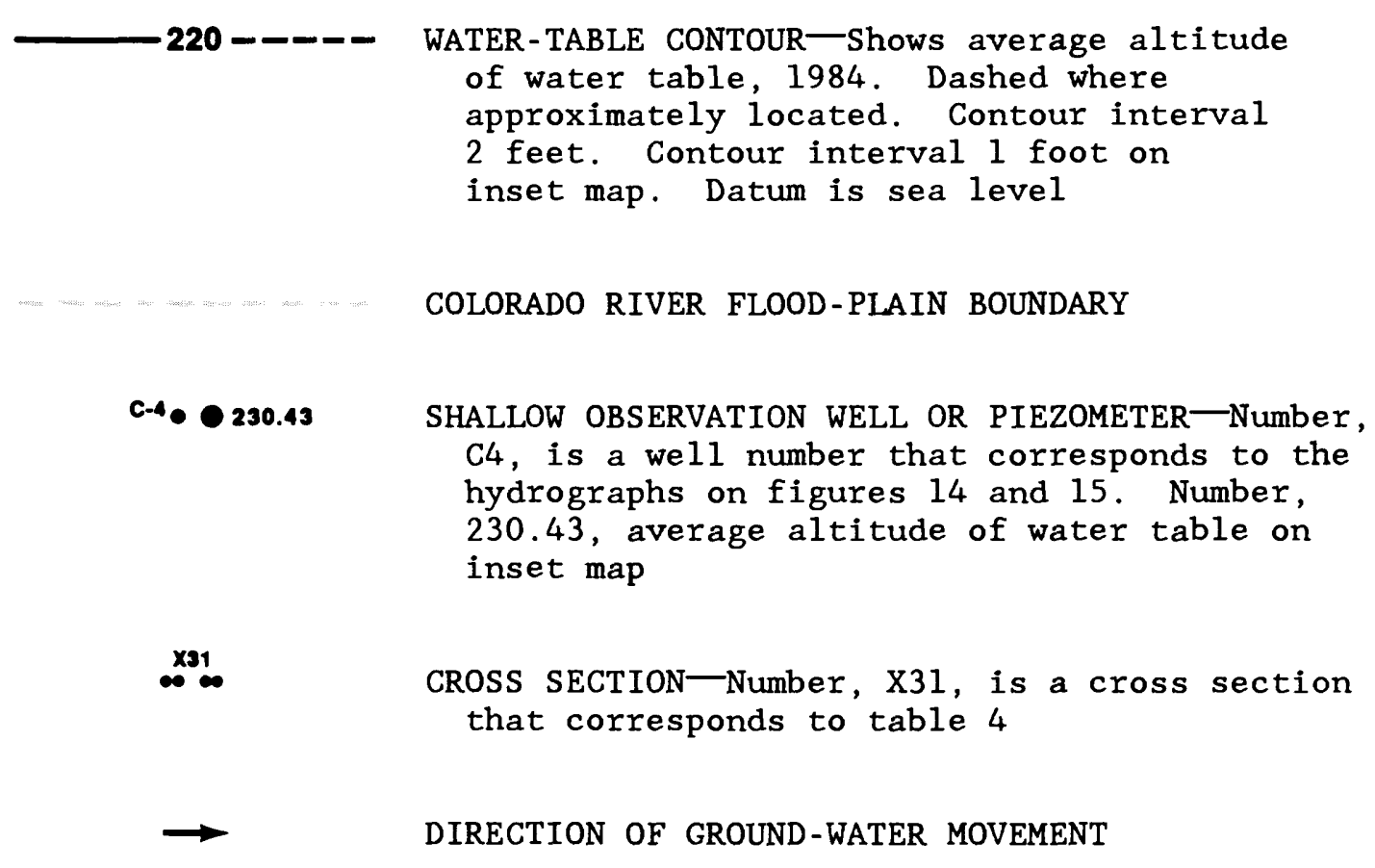


In Cibola Valley Irrigation and Drainage District where the flow direction is most variable within $500 \mathrm{ft}$ of the river, the quantity of water diverted from the river (table 2) and applied to crops was sufficient for crop evapotranspiration but was less than the total evapotranspiration calculated for crops and phreatophytes (table 1). The quantity of water applied but not used by the crops (potential ground-water return flow) was insufficient to meet the evapotranspiration requirements of the phreatophytes between the cropland and the river (fig. 3). Withdrawal of ground water by phreatophytes along the river would form an area of depression in the water table; such a depression is indicated by the contours that parallel the river between cross sections X29 and X32 (see insets on figs. 10 and 11 ). The ground water used by the phreatophytes is replaced by seepage from the river and potential ground-water return flow.

The drainage ditch did not affect the water-level contours in 1983 (fig. 10) and 1984 (fig. 11). The northern part of the ditch was damp but not deep enough to intersect the water table. The south end of the ditch did not empty into the river but emptied into a flooded area where the water table was above the land surface. Water in the southern part of the ditch appeared ponded with negligible flow and the banks were salt encrusted. The water level in the ditch represented the water table and the ditch was not acting as a drain.

In 1983, ground-water movement in the southern part of the valley was from the river eastward through the younger alluvium of the flood plain and across the flood-plain boundary into the older alluviums underlying the terraces (fig. 10). Water that seeped from the river went into storage in the older and younger alluviums. By 1984, the quantity of water in storage in the older alluviums began to approach an equilibrium with river stage as indicated by the water-level contours wrapping around to show ground-water movement toward the flood-plain boundary from both the younger and older alluviums (fig. 11).

\section{Changes in Ground-Water Levels}

Ground-water levels in Cibola Valley are controlled by stage in the river and recharge from excess river water applied for irrigation. During 1983 and 1984 , a rise in river stage that averaged more than $5 \mathrm{ft}$ caused water-level changes in the aquifer. Changes in annual average water levels were determined by subtracting the annual average water-table altitude of one year from that of the previous year. Maps were prepared to illustrate the magnitude and extent of the changes in water levels (figs. 12 and 13). The observation-well network was installed in Cibola Valley in February 1983 just before the flood-control releases began. To approximate the average change in water level during 1983 caused by the rise in river stage, a map was prepared to show the change in water level between February 1983 and December 1983 (fig. 12).

At times during 1983, the river stage was about $10 \mathrm{ft}$ higher than it was during 1982 ( $\mathrm{fig}$. 8). Ground-water levels rose more than 6 ft near the river in the northern part of the valley (fig. 12). Water levels declined in the east-central part of the valley because of less irrigation 
water applied to fields as a result of the PIK Program (table 5), domestic pumping east of the flood-plain boundary, and evaporation of water in the ditch.

Table 5. - Estimates of surface water applied to crops in Cibola Valley. Arizona, 1983-84, in acre-feet per year

Surface-water pumpage ${ }^{1}$ :

Cibola Valley Irrigation and Drainage District

15,325

19,180

Cropland south of Cibola Valley Irrigation and Drainage District ${ }^{2}$

Total (rounded):

${ }^{1}$ Determined from pumpage records (U.S. Bureau of Reclamation, 1985, p. 7 and $12 ; 1986$, p. 7 and 12 ).

${ }^{2}$ South of base line.

In 1984, sustained high river stage caused a continued rise in water levels throughout the flood plain, although the rise was less than in 1983. The annual average rise along most of the river was slightly less than $2 \mathrm{ft}$ but exceeded $2 \mathrm{ft}$ in the southern part of the valley and a small area in the northern part (fig. 13). The annual average rise that exceeded $2 \mathrm{ft}$ in the northern part of the valley was caused by a combination of the rise of the river and the increase in the quantity of water applied to fields in 1984. Water levels in the east-central part of the valley rose less than $1 \mathrm{ft}$. Water levels did not decline during 1984.

Hydrographs for selected wells in Cibola Valley show water-level changes from February 1983 through 1984 and show the relation between distance from the river and water-level changes on both sides of the river (fig. 14). Wells C22, C23, and $\mathrm{C} 24$ are from 0.2 to $1.05 \mathrm{mi}$ west of the river in an area that was not irrigated during 1983 and 1984 . Water levels near the river rose quickly to near or above the land surface as shown by the hydrograph of well C24. Farther from the river, the rise was more gradual and, during the summer months of 1983 and 1984 , water-level declines were associated with the consumptive use of ground water by dense stands of phreatophytes.

Wells C25, C26, and C27 are from 0.25 to $0.7 \mathrm{mi}$ east of the river and show water-level changes associated with the rise in river stage near the river and some irrigation of cropland away from the river (fig. 14). The rise in water level in well C25 corresponds closely with river stage (fig. 8). Wells C26 and C27 are on the north edge of a field that contained irrigated alfalfa during 1983. In 1984, the field was not irrigated but some volunteer alfalfa did grow and, on the basis of the 


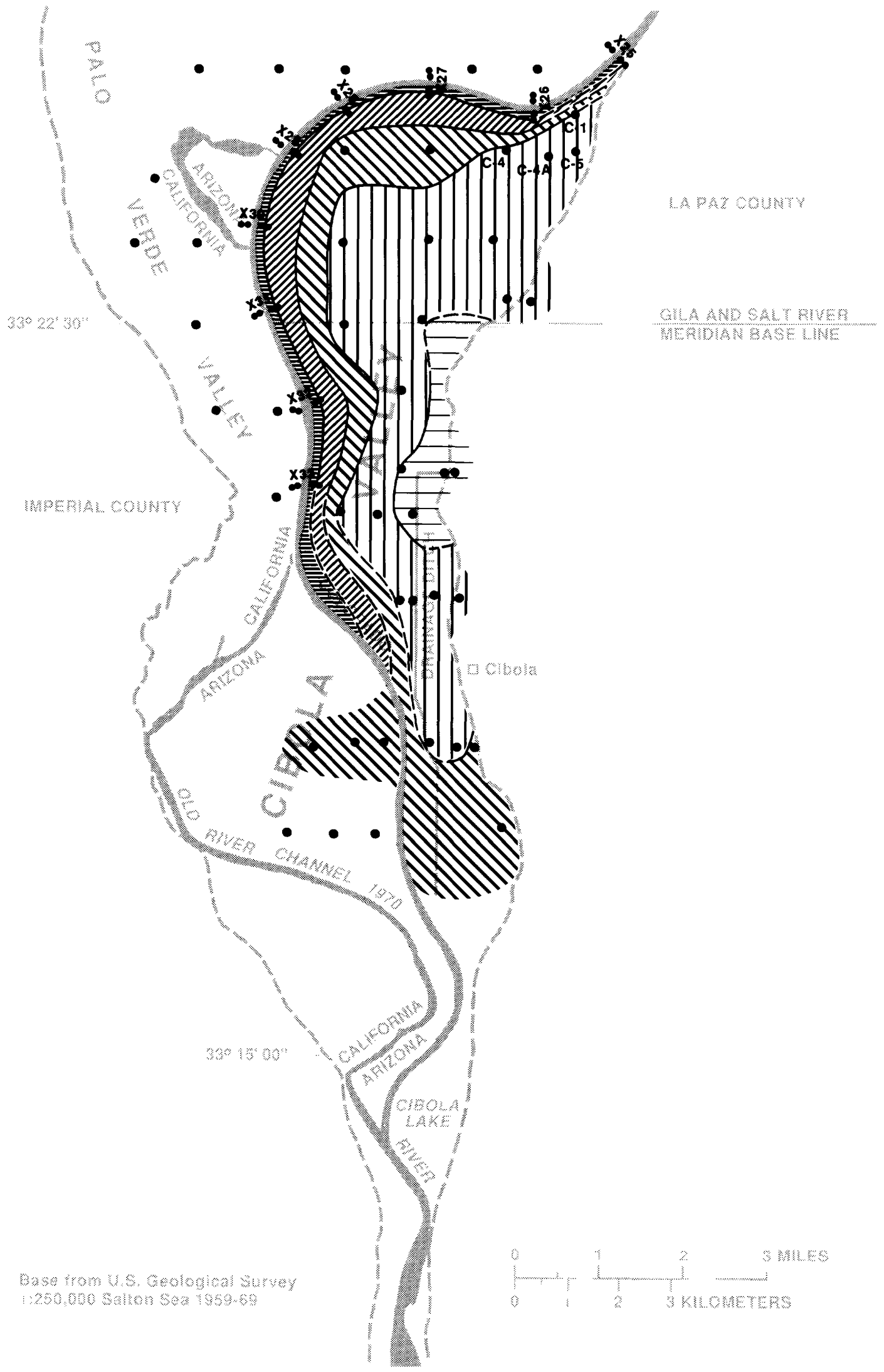

Figure 12.--Change in ground-water levels in Cibola Valley, Arizona, February 1983-December 1983. 
E X P L A N A T I O N

WATER-LEVEL CHANGE, IN FEET

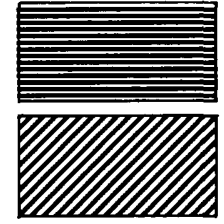

More than 6

4 to less than 6

2 to less than 4

凹ा川ा川

0 to less than 2

Less than 0

COLORADO RIVER FLOOD-PLAIN BOUNDARY

SHALLOW OBSERVATION WELL OR PIEZOMETER-Number, $C 4$, is a well number that corresponds to the hydrographs in figures 14 and 15

CROSS SECTION-Number, $\mathrm{X} 31$, is a cross section that corresponds to table 4 


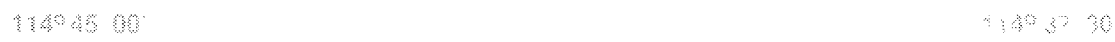

30

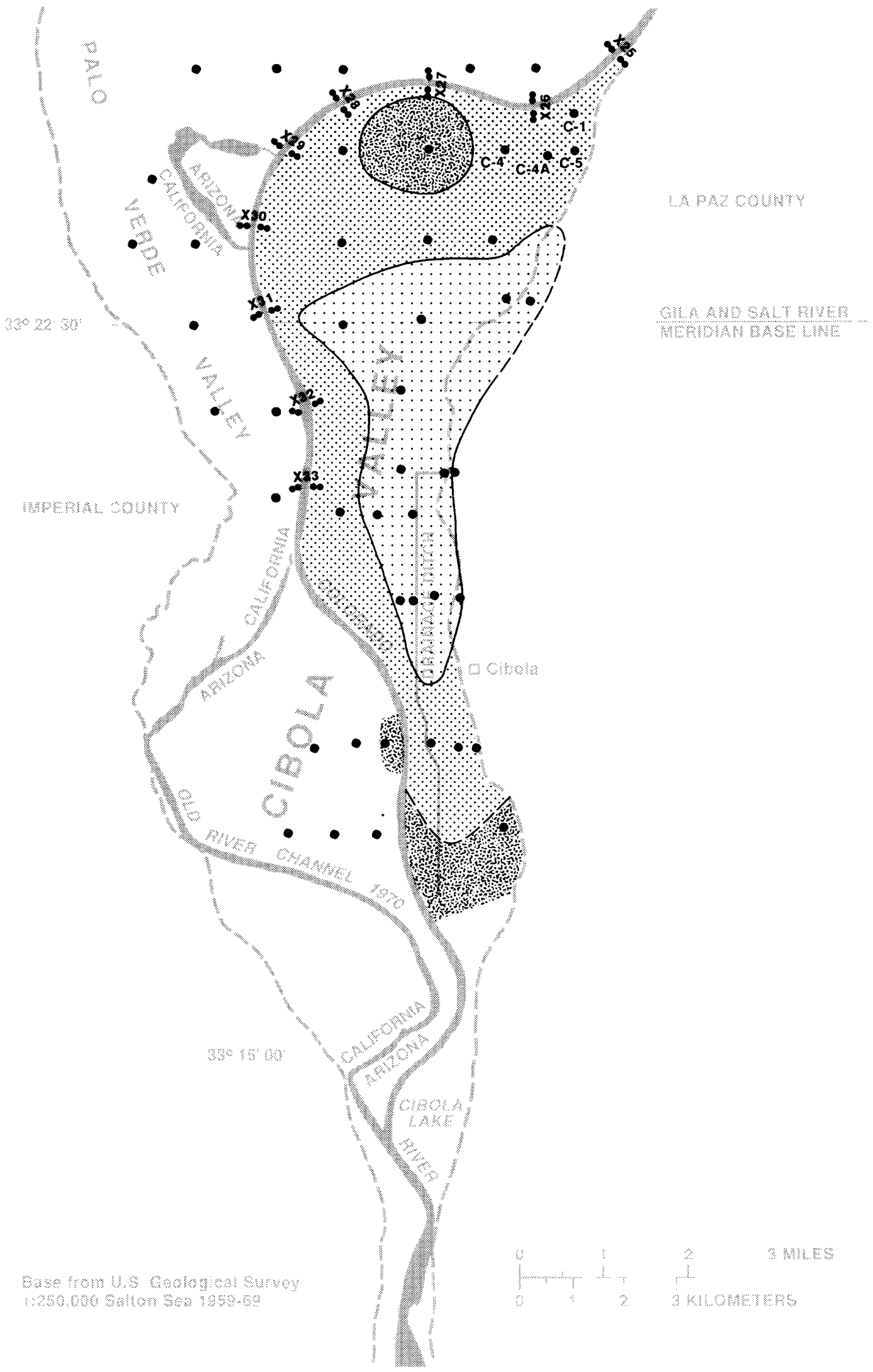

Figure 13.-- Change in annual average ground-water levels in Cibola Valley, Arizona, 1983-84. 
E X P L A N A T I O N

ANNUAL AVERAGE WATER-LEVEL CHANGE, IN FEET

More than 2

1 to 1 ess than 2

0 to less than 1

COLORADO RIVER FLOOD-PLAIN BOUNDARY

SHALLOW OBSERVATION WELL OR PIEZOMETER-Number, C4, is a well number that corresponds to the hydrographs in figures 14 and 15

$\underset{\infty}{x} \times 1$

CROSS SECTION-Number, $\mathrm{X} 31$, is a cross section that corresponds to table 4 

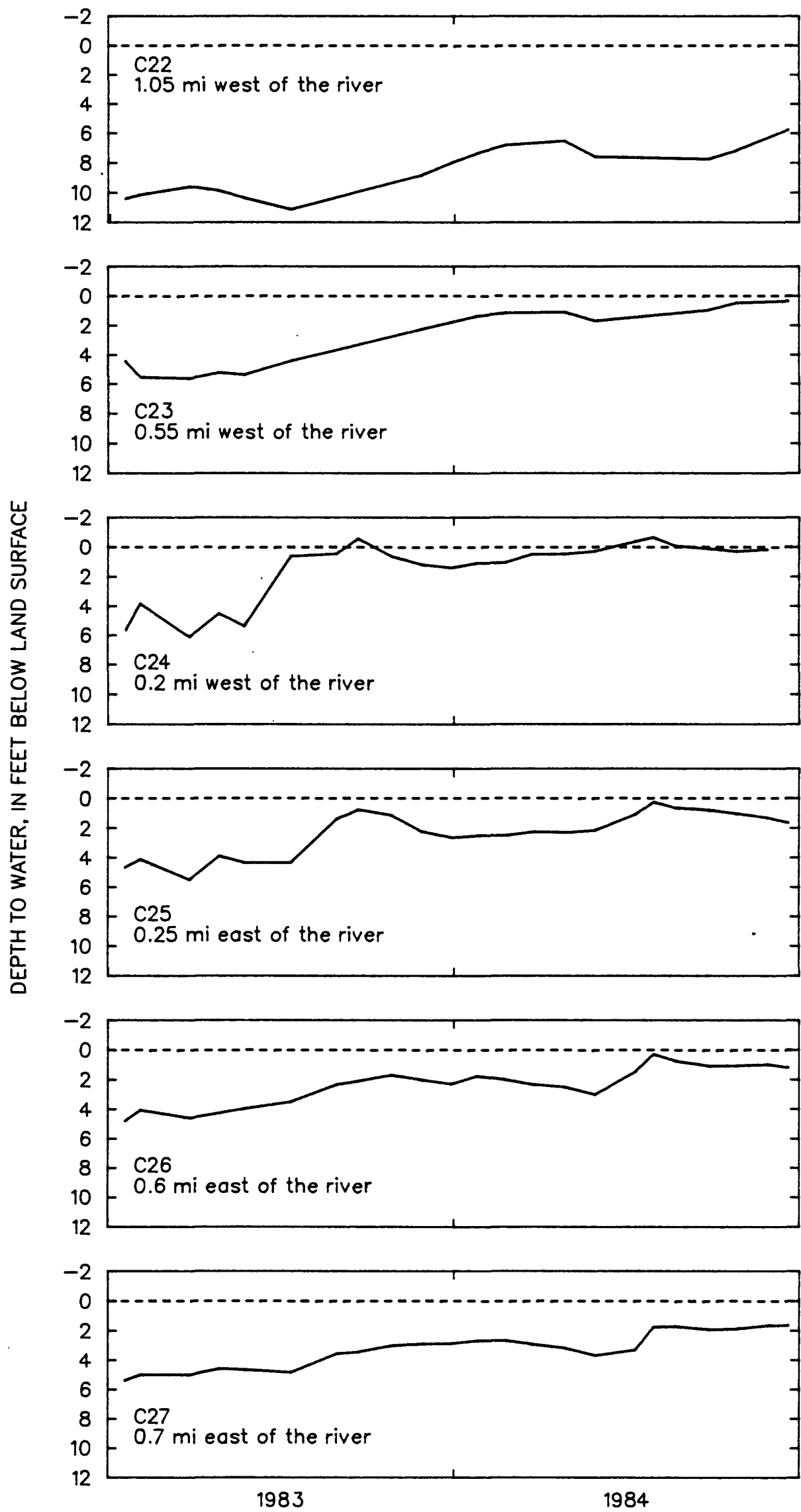

Figure 14.--Water levels in selected we11s in Cibola Valley, Arizona, 1983-84. 
shape of the hydrograph during the middle of the year, consumed ground water (fig. 14). Some fields had new saltcedar growth as volunteer vegetation. Water-level changes in we11s $C 26$ and $C 27$ were more gradual than those in well C25 near the river and did not show the summer declines associated with water use by the dense phreatophyte areas across the river.

\section{Change in Storage}

Change in ground-water storage was calculated as the product of changes in ground-water levels, areas of change, and specific yield. Changes in ground-water levels were based on the differences between annual average water levels in wells. Areas of change were determined by measuring the areas between the contours on figures 12 and 13 . A specific yield of 0.32 was measured for sediments above the water table during soil-moisture studies in Palo Verde Valley, which is northwest of and across the Colorado River from Cibola Valley (Metzger and others, 1973, p. 72). The value of specific yield was transferred for use in calculating change in storage to Cibola Valley, where the near-surface materials beneath the flood plain are similar to those in Palo Verde Valley. Ground-water storage was estimated to increase by 4,500 acre-ft in Cibola Valley from 1983 to 1984 .

Data were not available to calculate annual average change in storage from 1982 to 1983 because the observation wells were not installed until February 1983. An approximation of the annual change in ground-water storage was made by using water levels, which were measured in February 1983 prior to the flood-control releases in the river. Ground-water storage between February and December 1983 was estimated to increase by 10,800 acre-ft, which represents the quantity of water that went into storage during the period of rising river stage.

The annual increase in the quantity of ground water in storage and the quantity retained in storage from year to year because of high river stage will significantly affect the estimation of ground-water return flow when the river stage subsides. During the years of receding flow when releases from the dam are transitioned from flood control to downstream requirements, bank storage will return to the river mixed with ground-water return flow from applied irrigation water.

\section{Relation of the Alluvial Aquifer to the Underlying Aquifer}

We11 C4A (we11 A of Metzger, 1965, p. 205) is an unused irrigation well drilled in 1964 in the northern part of Cibola Valley (fig. 10) and is the southernmost of a group of wells perforated in the fanglomerate aquifer between Parker Dam and Cibola Valley. The well is perforated in the fanglomerate from 800 to $1,000 \mathrm{ft}$ below the land surface and is the only well in the Cibola Valley that penetrates the fanglomerate. We11 C4A was reported to have little or no positive artesian head, an unexplained anomaly in 1964 (Metzger, 1965, p. 205). Al1 other wells had positive artesian head (where the water level stands above the local water table), which increased from north to south. Artesian conditions exist in 
the fanglomerate because of the fine-grained nature of the overlying Bouse Formation; between the Colorado River alluvium and the fanglomerate is $550 \mathrm{ft}$ of blue clay. Ground water discharges from the fanglomerate through the alluvium south of Cibola at the constriction of the valley where the fanglomerate and Bouse Formation dip northward and crop out in the adjacent canyon walls (Metzger and others, 1973, p. 46).

During this study, additional data were collected from the well owner that show the well is also perforated in the alluvium from 60 to $200 \mathrm{ft}$ below the land surface (Wayne Sprawls, written commun., 1983). Water samples were collected at the time the well was drilled from (1) the fanglomerate aquifer and (2) the fanglomerate and alluvial aquifers combined. When the well was open only in the fanglomerate, the water level was reported as $135 \mathrm{ft}$ below the land surface, indicating negative artesian head in the fanglomerate because the water level stood about $114 \mathrm{ft}$ below the water table in the alluvium.

During 1983 and 1984 , water levels were measured monthly in well C4A in addition to the network of shallow observation wells on the flood plain (fig. 10). The water level measured in January 1983 prior to the rise in river stage was $21.34 \mathrm{ft}$ below the land surface, or $0.29 \mathrm{ft}$ lower than the water level measured in October 1964-no significant net change in 20 years. In February 1983, the altitude of the water level in we11 C4A was about $10 \mathrm{ft}$ lower than those in nearby shallow observation wells $\mathrm{Cl}$, C4, and C5 (fig. 15), which indicates a downward gradient and the potential for leakage from the alluvium to the fanglomerate.

The water level in well C4A rose in response to rising river stage and followed the same general trend as water levels in the nearby shallow wells. Between February and August of 1983, the water level in well C4A rose about $5 \mathrm{ft}$; in the three shallow wells, the water level rose about $3 \mathrm{ft}$. The similar response time for both aquifers indicates that the water-level rise in well $\mathrm{C} 4 \mathrm{~A}$ was caused by the increase in head in the alluvium.

Leakage through the confining clay of the intervening Bouse Formation is unlikely, as indicated by the differences in the altitudes of the water levels in the fanglomerate and the alluvium. A small amount of leakage occurs through the well casing in only one we11; however, leakage between aquifers is negligible as a component in the water budget.

\section{CONSUMPTIVE USE}

Water-use rates by crop type were calculated using the Blaney-Criddle equation (Blaney and Criddle, 1950) and consumptive use by vegetation was estimated using equation 1 . The water-use rate for phreatophytes was not calculated using the Blaney-Criddle equation because empirical consumptive-use coefficients ( $K$ values) were not available for the phreatophyte species mixture along the Colorado River.

Evapotranspiration by phreatophytes was calculated by using the water-use rate determined for the phreatophyte mixture south of Palo Verde 


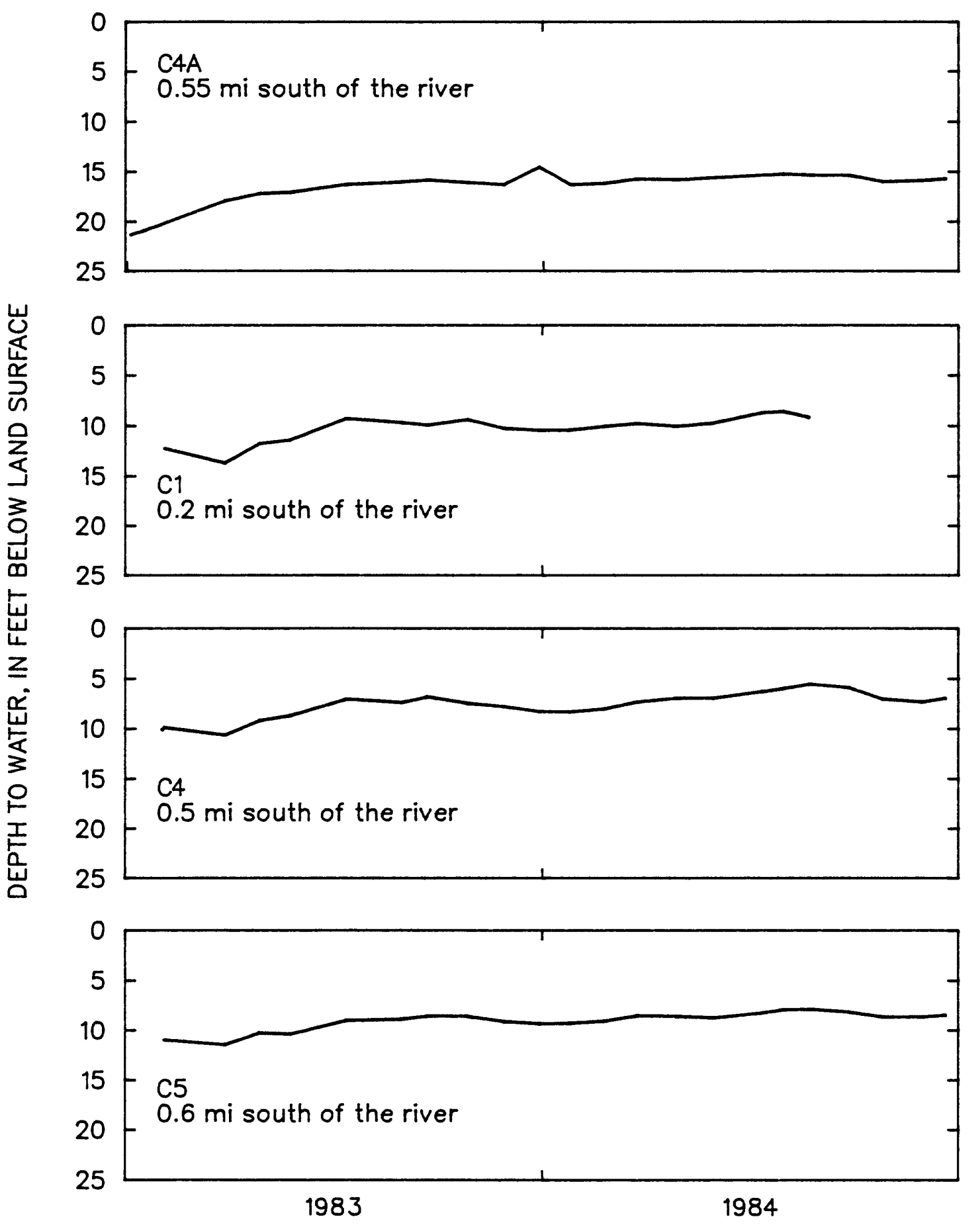

Figure 15.--Water levels in a well in the fanglomerate aquifer and in three nearby wells in the alluvium, 1983-84. 
Dam by Boyle Engineering Corp. (1976, p. II-7). Crop types were mapped for each field in Cibola Valley during 1983 and 1984. Crop and phreatophyte areas were mapped from aerial photographs taken in November 1982 and August 1985.

Evapotranspiration was calculated as the sum of the products of the area of each vegetation type and the water-use rate by vegetation type. Evapotranspiration east of the river in Cibola Valley was estimated to be 44,700 acre-ft in 1983 and 40,500 acre-ft in 1984 (table 1). Evapotranspiration west of the river between the old and new channels and on the California side of the old river channel was estimated to be 25,400 acre-ft in 1983 and 22,100 acre-ft in 1984. Crops were not grown west of the river during these years. The fields were not irrigated but volunteer vegetation grew and used ground water in 1983. In 1984 many of the fields were flooded where the water table was above the land surface.

Total evapotranspiration for Cibola Valley is the sum for the areas east of the river, between the old and new channels, and west of the old channel and north of the gaging station (fig. 2, site 4). Evapotranspiration was estimated to be 70,100 acre-ft in 1983 and 62,600 acre-ft in 1984. These estimates are low because evaporation from the increased and varying open-water surfaces in flooded phreatophyte areas could not be estimated.

Rising river stage in 1983 flooded areas directly or raised the ground-water levels above the land surface. In areas without levees south of Cibola Lake, water flowed directly into areas of phreatophytes. In areas with levees, water flowed through the levees and raised ground-water levels above the land surface to flood areas of phreatophytes and some cropland between the old and new river channels and around Cibola Lake. During 1983-84, parts of the lower levees, which bound the channel in the southern part of the valley, were under water. The inundated area changed through time as a function of river stage, which made it impractical to determine the increase in evaporation from the water surface as a component of evapotranspiration. The effect of sustained inundation on the water-use rates for the phreatophytes is unknown; therefore, adjustments to rates calculated for dry-surface conditions could not be made. A lower limit on the size of the inundated area corresponds with the size of the area mapped in 1985 -about 4,400 acres where phreatophytes died from sustained inundation.

Sustained high river stage maintained the flooded areas through 1984 and 1985. Infrared aerial photographs taken in August 1985 document some of the changes in areas of phreatophytes caused by the flooding that impact the estimation of consumptive use by vegetation. Short-term inundation with fresh water resulted in new phreatophyte growth in some areas. In other areas where the water table remained above the 1 and surface, many phreatophytes died. In Cibola Valley, including the area east of the old channel, about 1,650 acres of phreatophytes died; another 2,700 acres of phreatophytes died west of the old river channel. The change in area of phreatophytes was incorporated into the estimation of evapotranspiration.

The relation between evapotranspiration and consumptive use by vegetation was determined for 1983 and 1984 in similar studies of Palo 
Verde Valley (Owen-Joyce and Kimsey, 1987; Raymond and Owen-Joyce, 1987 ) and Parker Valley (Owen-Joyce, 1988). In Palo Verde Valley, evapotranspiration was 9 percent less than consumptive use by vegetation in 1983 and 1 percent higher in 1984. In Parker Valley, evapotranspiration was 5 percent higher than consumptive use by vegetation in 1983 and 3 percent higher in 1984 .

After these additional studies in Palo Verde and Parker Valleys, the percentage differences between evapotranspiration and consumptive use by vegetation in Palo Verde Valley are not considered transferable for use in Cibola Valley for 1983 and 1984. Hydrologic conditions were variable within each valley and from one valley to another because of the high river stage and the PIK Program. The relation between evapotranspiration and consumptive use by vegetation in Palo Verde and Parker Valleys was not consistent although the difference was within \pm 10 percent. In 1983 , consumptive use by vegetation in Palo Verde Valley was less than evapotranspiration, whereas in 1984 the reverse occurred. Several reasons for the change in the relation were identified but could not explain the change (Raymond and Owen-Joyce, 1987, p. 23-24). Because the change in relation between the two values could not be explained, the transfer of values from Palo Verde Valley for use in Cibola Valley could not be justified. Between 1983 and 1984 , no reverse of the relation between the two values occurred in Parker Valley; during both years, evapotranspiration was higher than consumptive use by vegetation (Owen-Joyce, 1988). Both valleys have more than 50,000 acres cultivated with a similar crop selection. Cibola Valley has less than 5,000 acres cultivated, and the acreage does not include the other crops such as lettuce, melons, onions, tomatoes, and garlic that are grown in Palo Verde and Parker Valleys. In Cibola Valley, a larger percentage of its area was inundated by river water or by the water table rising above the land surface than in Parker and Palo Verde Valleys during 1983 and 1984. Measurement of that surface area is difficult because of changes throughout the year.

Evapotranspiration varies with depth to water for phreatophytes (Anderson, 1976, p. 47) and, depending on the depth of the water and length of time of inundation, phreatophytes can either sprout new growth or die. The effect of the differences between the valleys cannot be quantified; therefore, the estimate of evapotranspiration is used as an approximation for the estimate of consumptive use by vegetation.

\section{GROUND-WATER RETURN FLOW}

Annual ground-water return flow to the river calculated by using equation 4 is dependent on the existence of a ground-water divide underlying the irrigated area. Ground-water return flow from applied irrigation water must reach the mainstream of the river and be available for use downstream in order to be credited against the diversion. Annual average water-table contours for 1983 (fig. 10) and 1984 (fig. 11) show that most reaches of the river lost water to the aquifer except locally near the base line. Ground-water return flow to the Colorado River from Cibola Valley probably was negligible in 1983 and 1984. 


\section{DIVERSIONS MINUS RETURN FLOWS}

Consumptive use of Colorado River water calculated as diversions minus return flows by using equation 3 for Cibola Valley in 1983 and 1984 is equal to the quantity of water pumped by users during those years. Cibola Valley has no drainage ditches that return water to the river and therefore there are no measured surface-water return flows. Most of Cibola Valley drained in the subsurface away from the river, which resulted in negligible ground-water return flow. In 1983 and 1984, water users pumped and consumptively used 21,800 and 24,600 acre-ft of water from the river, respectively.

\section{COMPARISON OF CONSUMPTIVE-USE ESTIMATES}

A comparison of the estimates of evapotranspiration by crops to the quantity of water pumped from the river and applied to cropland shows that in both years the diversion exceeded the estimate of evapotranspiration by crops. Evapotranspiration by crops was 18,735 acre-ft in 1983, or 85.9 percent of the diversion, and 19,345 acre-ft in 1984 , or 78.6 percent of the diversion. Evapotranspiration by vegetation exceeded the measured diversion of river water to cropland because of the additional evapotranspiration by phreatophytes.

Potential ground-water return flow, the difference between the quantity of water diverted from the river and applied to cropland and evapotranspiration by crops, is 28.3 to 54.5 percent less than the estimate of evapotranspiration by phreatophytes in the area north of base line and 75.2 to 88.2 percent less than the estimate of evapotranspiration by phreatophytes east of the river. Any potential ground-water return flow does not return to the river but is used by the phreatophytes. Evapotranspiration by phreatophytes is large enough, 51,400 acre-ft in 1983 and 43,300 acre-ft in 1984, to maintain induced seepage from the river in the reach adjacent to Cibola Valley to replace the ground water consumed.

\section{SUMMARY}

Water is pumped from the Colorado River in Cibola Valley, Arizona, to irrigate crops and to maintain wildlife habitat. Unused water percolates to the water table and as ground water drains to areas of phreatophytes, to a drainage ditch in the Cibola National Wildlife Refuge, out of the flood plain, and back to the river. In 1983 and 1984, the river adjacent to and through Cibola Valley lost water except for localized areas near the Gila and Salt River meridian base line.

The estimate of evapotranspiration, calculated as the sum of the products of the areas of vegetation types and the water-use rates by vegetation type, is used as an approximation for the estimate of consumptive use by vegetation. Evapotranspiration was estimated to be 70,100 acre-ft in 1983 and 62,600 acre-ft in 1984. The estimates are low because evaporation from the increased and varying open-water surfaces in 
flooded phreatophyte areas could not be estimated. The effect of sustained inundation on the water-use rates for phreatophytes is unknown; therefore, adjustments to rates calculated for dry-surface conditions could not be made.

The method of estimating consumptive use by vegetation and ground-water return flow is affected by the changing hydrologic conditions during years of rising and sustained high river stage. High river stage flooded areas directly or raised ground-water levels above the land surface. No crops could be grown in flooded fields. The decreased depth to water and short-term inundation with fresh water resulted in new phreatophyte growth in some areas. In areas of sustained flooding, many phreatophytes died. The changes in the inundated and flooded areas throughout 1983 and 1984 made it difficult to estimate the evaporation from the increased water surface. In addition, the estimation of irrigation return flow to the river through the ground-water system when the river stage subsides will be significantly affected by the return of ground water to the river that did not originate as irrigation water.

Changes in cropping patterns as a result of the Payment-In-Kind Program also affected the estimation of consumptive use by vegetation. The relation between the estimates of evapotranspiration and consumptive use by vegetation in Palo Verde Valley, which was assumed to be transferable for use in Cibola Valley in 1981 in a previous study, is not an applicable assumption. The relation between the two estimates in $\mathrm{Palo}$ Verde and Parker Valleys - two valleys of similar size and crop mix were not the same; therefore, transferability to a smaller valley with a different crop mix and a larger percentage of its area flooded is not appropriate. The estimate of evapotranspiration was used as an approximation for the estimate of consumptive use by vegetation during years of rising and sustained high river stage.

\section{SELECTED REFERENCES}

Anderson, B.W., and Ohmart, R.D., 1976, Vegetation type maps of the lower Colorado River from Davis Dam to southerly international boundary: Phoenix, Arizona State University duplicated report, 4 p., 23 pls.

Anderson, T.W., 1976, Evapotranspiration losses from flood-plain areas in central Arizona: U.S. Geological Survey Open-File Report 76-864, $91 \mathrm{p}$.

Blaney, H.F., and Criddle, W.D., 1950, Determining water requirements in irrigated areas from climatological and irrigation data: U.S. Department of Agriculture, Soil Conservation Service, Technical Paper $96,48 \mathrm{p}$.

Bookman-Edmonston Engineering, Inc., 1976, Reduction of salt loading to the Colorado River from Palo Verde Irrigation District: Glendale, California, Report prepared for U.S. Bureau of Reclamation, $75 \mathrm{p}$. 
Boyle Engineering Corp., 1976, Salinity control and irrigation system analysis, Colorado River Indian Reservation, Yuma County, Arizona: Phoenix, Report prepared for U.S. Bureau of Reclamation, 267 p.

Leake, S.A., 1984, A method for estimating ground-water return flow to the Colorado River in the Parker area, Arizona and California: U.S. Geological Survey Water-Resources Investigations Report 84-4229, $31 \mathrm{p}$.

Loeltz, 0.J., and Leake, S.A., 1983, A method for estimating ground-water return flow to the lower Colorado River in the Yuma area, Arizona and California: U.S. Geological Survey Water-Resources Investigations Report 83-4220, 86 p.

Metzger, D.G., 1965, A Miocene(?) aquifer in the Parker-Blythe-Cibola area, Arizona and California, in Geological Survey Research 1965: U.S. Geological Survey Professional Paper 525-C, p. C203-C205.

Metzger, D.G., 1968, The Bouse Formation (P1iocene) of the Parker-BlytheCibola area, Arizona and California, in Geological survey Research 1968: U.S. Geological Survey Professional Paper 600-D, p. D126-D136.

Metzger, D.G., and Loeltz, 0.J., 1973, Geohydrology of the Needles area, Arizona, California, and Nevada: U.S. Geological Survey Professional Paper 486-J, 54 p.

Metzger, D.G., Loeltz, 0.J., and Irelan, Burdge, 1973, Geohydrology of the Parker-Blythe-Cibola area, Arizona and California: U.S. Geological Survey Professional Paper 486-G, 130 p.

National Climatic Data Center, 1980-84, Climatological data, Arizona: U.S. Department of Commerce (published monthly).

Owen-Joyce, S.J., 1984, A method for estimating ground-water return flow to the Colorado River in the Palo Verde-Cibola area, California and Arizona: U.S. Geological Survey Water-Resources Investigations Report 84-4236, $48 \mathrm{p}$.

Owen-Joyce, S.J., 1988, Estimates of consumptive use and ground-water return flow using water budgets in Parker Valley, Arizona and California, 1981-84: U.S. Geological Survey Water-Resources Investigations Report 88-4063, $64 \mathrm{p}$.

Owen-Joyce, S.J., and Kimsey, S.L., 1987, Estimates of consumptive use and ground-water return flow using water budgets in Palo Verde Valley, California: U.S. Geological Survey Water-Resources Investigations Report $87-4070,50 \mathrm{p}$.

Raymond, L.H., and Owen-Joyce, S.J., 1986, Estimates of consumptive use and evapotranspiration in Palo Verde Valley, California, 1981 and 1983, in Johnson, A.I., and Rango, A., eds., Remote Sensing Applications for Consumptive Use (Evapotranspiration): American Water Resources Association Monograph Series No. 6, p. 25-34. 
Raymond, L.H., and Owen-Joyce, S.J., 1987, Comparison of estimates of evapotranspiration and consumptive use in Palo Verde Valley, California: U.S. Geological Survey Water-Resources Investigations Report 87-4071, $27 \mathrm{p}$.

Raymond, L.H., and Rezin, K.V., 1989, Evapotranspiration estimates using remote-sensing data, Parker and Palo Verde Valleys, Arizona and California: U.S. Geological Survey Water-Supply Paper 2334, $18 \mathrm{p}$.

U.S. Bureau of Reclamation, 1985, Compilation of records in accordance with Article $V$ of the Decree of the Supreme Court of the United States in Arizona v. California dated March 9, 1964, calendar year 1983: U.S. Bureau of Reclamation duplicated report, $35 \mathrm{p}$.

1986, Compilation of records in accordance with Article $\mathrm{V}$ of the Decree of the Supreme Court of the United States in Arizona v. California dated March 9, 1964, calendar year 1984: U.S. Bureau of Reclamation duplicated report, $34 \mathrm{p}$.

U.S. Supreme Court, 1964, State of Arizona, plaintiff v. State of California, et al., defendants: Decree-March 9, 1964, no. 8, original, $14 \mathrm{p}$. 